\title{
Berthierine and chamosite hydrothermal: genetic guides in the Peña Colorada magnetite-bearing ore deposit, Mexico
}

\author{
M. L. Rivas-Sanchez ${ }^{1}$, L. M. Alva-Valdivia ${ }^{1}$, J. Arenas-Alatorre ${ }^{2}$, J. Urrutia-Fucugauchi ${ }^{1}$, \\ M. Ruiz-Sandoval ${ }^{3}$, and M. A. Ramos-Molina ${ }^{3}$ \\ ${ }^{1}$ Laboratorio de Paleomagnetismo y Geofísica Nuclear, Instituto de Geofísica, Universidad Nacional Autónoma de México, \\ México (D. F.) 04510 México \\ ${ }^{2}$ Laboratorio Central de Microscopía, Instituto de Física, Universidad Nacional Autónoma de México, \\ México (D. F.) 04510 México \\ ${ }^{3}$ Dirección General y Dirección de Tecnología, Consorcio Minero Benito Juárez, Peña Colorada, S. A. de C. V., \\ Av. del Trabajo No. 1000, Manzanillo, Colima, México
}

(Received December 14, 2005; Revised June 1, 2006; Accepted June 6, 2006; Online published November 8, 2006)

\begin{abstract}
We report the first finding of berthierine and chamosite in Mexico. They occur in the iron-ore deposit of Peña Colorada, Colima. Their genetic characteristics show two different mineralization events associated mainly to the magnetite ore. Berthierine is an Fe-rich and Mg-low 1:1 layer phyllosilicate of hydrothermal sedimentary origin. Its structure is $7 \AA, d_{h k l}\left[\begin{array}{lll}1 & 0 & 0\end{array}\right]$ basal spacing and low degree structural ordering. The phyllosilicate has been identified by a lack of $14 \AA$ basal reflection on X-ray diffraction (XRD) patterns. These data were supported by High Resolution Transmision Electron Microscopy (HRTEM) images that show thick packets of berthierine in well defined parallel plates. From the analysis of Fast Fourier Transform (FFT), we found around $\left[\begin{array}{lll}1 & 0 & 0\end{array}\right]$ reflections of berhierine $7.12 \AA$ and corresponding angles of hexagonal crystalline structure. Berthierine has a microcrystalline structure, dark green color, and high refraction index (1.64 to 1.65). Birefringence is low, near 0.007 to null and it is associated to nanoparticles $(<15 \mathrm{~nm})$ and microparticles of magnetite $(<25 \mu \mathrm{m})$, fine grain siderite, and organic matter. Its texture is intergranular-interstratified with colloform banding. The chamosite Mg-rich is of hydrothermal epigenetic origin affected by low-degree metamorphism. It is an Fe-rich 2:1 layer silicate, with basal space of $14 \AA, d_{h k l}\left[\begin{array}{lll}0 & 0 & 1\end{array}\right]$. The chamosite occurs as lamellar in sizes ranging from 50 to $150 \mu \mathrm{m}$. It has intense green color and refraction index from 1.64 to 1.65 . The birefringence is near 0.008 , with biaxial (-) orientation and a $2 \mathrm{~V}$ small. It is associated mainly to sericite, epidote, clay, feldspar, and magnetite. Chamosite is emplaced in open spaces filling and linings. Mössbauer spectra of berthierine and chamosite are similar. They show the typical spectra of paramagnetic substances, with two well defined unfoldings corresponding to the oxidation state of $\mathrm{Fe}^{+2}$ and $\mathrm{Fe}^{+3}$. Chemical composition of both minerals was obtained by an electron probe X-ray micro-analyzer (EPMA). The radio $\mathrm{Fe}+\mathrm{Mg}+\mathrm{Mn}$ vs $\mathrm{Si}$ and Al show similar chemical compositions and different XRD patterns in the crystalline structure provoked by the environmental conditions of emplacement. A hydrothermal environment was predominant, occurring before, during, and after the magnetite mineralization. The identification of magnetite nanoparticles supports the hypothesis of a marine environment, specifically exhalative sedimentary (SEDEX) for the berthierine.
\end{abstract}

Key words: Berthierine, chamosite, magnetite nanoparticles, iron-ore, SEDEX, Peña Colorada, Mexico.

\section{Introduction}

Berthierine and chamosite are relatively scarce minerals in nature, approximately just around 15 localities around the world are known associated to iron deposits. Some are SEDEX in origin (Damyanov and Vassileva, 2001; Xu and Veblen, 1996; Kimberley, 1989; Curtis and Spears, 1968 Wiewiora et al., 1998), other sulfide massive volcanogenic (Slack et al., 1992), metamorphic origin (Wybrecht et al., 1985), and associated to bauxite and laterite (White et al., 1985; Toth and Fritz, 1997). These minerals also occur in Northampton ironstone (Hirt and Gehring, 1991), in paleosol near Waterval Onder, South Africa (Retallack, 1986), in the oolitic ironstone beds, Hazara, Lesser Himalayan

Copyright (c) The Society of Geomagnetism and Earth, Planetary and Space Sciences (SGEPSS); The Seismological Society of Japan; The Volcanological Society of Japan; The Geodetic Society of Japan; The Japanese Society for Planetary Sciences; TERRAPUB thrust zone (Yoshida, 1998), in metamorphic rock in the Sierra Albarrana pegmatite body (Del Mar Abad-Ortega and Nieto, 1995), in the coal-swamp deposits in Paleogene and Upper Triassic coal, Japan (Iijima and Matsumoto, 1982).

This is the first report of berthierine and chamosite in the magnetite-bearing ore deposit of Peña Colorada, México. It is located to the north of the Sierra Madre del Sur, in the northwestern part of the Colima State (Fig. 1). It is the major iron-ore deposit of Mexico. It has 173 million tons of ore reserves of high-grade Fe magnetic. We made mineralogical, physicochemical, and textural studies of the high-degree-of-purity berthierine and chamosite obtained through a metallurgical process, together with other representative minerals associated to the main ore (magnetite). Berthierine and chamosite are considered good indicators of the geological processes and conditions under which this 


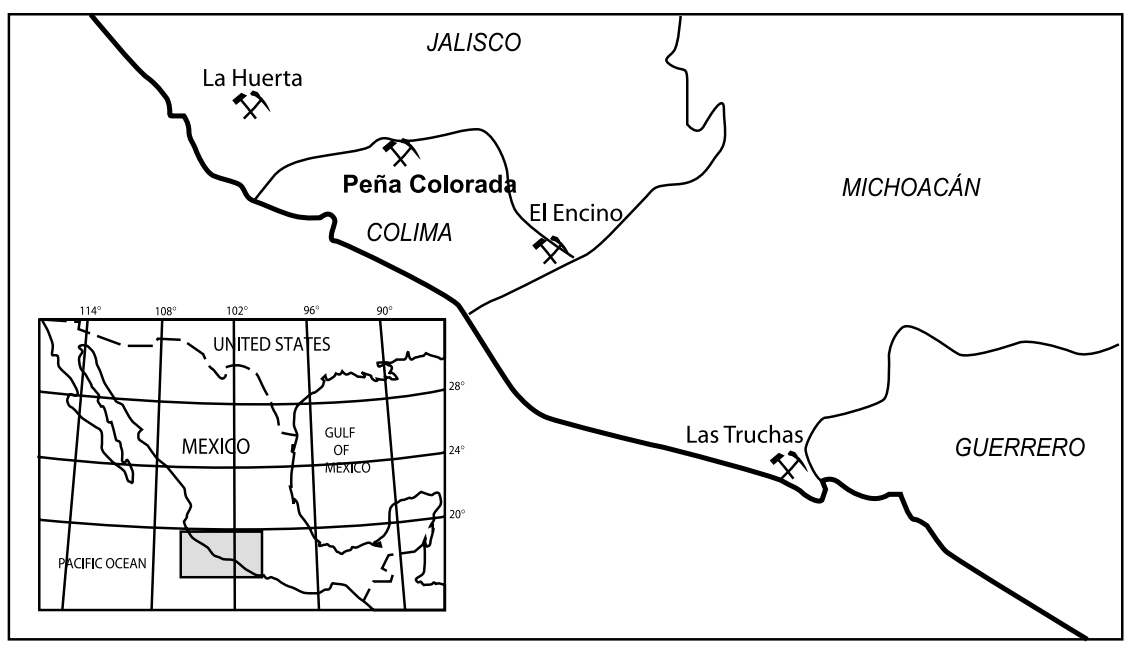

Fig. 1. Localization of the study area.

deposit was formed. Thus, they represent an important key in the knowledge of the environmental characteristics that contribute to the formation of important iron-ore deposits in the world (Damyanov and Vassileva, 2001; Slack et al., 1992; Bhattacharyya, 1983). The results obtained support the hypothesis of a SEDEX origin for this deposit.

SEDEX deposits are formed from the hydrothermal fluid discharge on the Earth crust surface in a marine environment. The basins of extensional type provoke the tectonic activity that accompanied the fluid ascent along the active faults and the discharge through the hot springs, producing chemical precipitation (exhalites) deposited on the marine floor. The constant repetition of hydrothermal fluids discharge and the exhalite formation provoke sedimentation processes, compaction and diagenesis during the evolution of the sedimentary basin (Pirajno, 1992). These processes are important components in the formation of exhalative sedimentary deposits.

For the mineralogical characterization we applied several methodologies to analyze berthierine and chamosite minerals associated to magnetite and their textural relations (size and shape). Main objectives include: (1) studies of mineralogical features, mineral association and texture relation that were completed using reflected-transmitted light microscopy, XRD, EPMA and Mössbauer spectroscopy; (2) identification of magnetite nanoparticles investigated through HRTEM.

This study shows a complex mineralogy divided into two paragenetic types: (1) chamosite of hydrothermal epigenetic origin associated mainly to massive/disseminated magnetite-sericite-clay mineral quartz and epidote; and (2) berthierine of hydrothermal origin, due to hydrothermalism and diagenetic processes in a SEDEX environment. Berthierine is associated to siderite, organic matter and micro-nanoparticles of botryoidal magnetite.

\section{Material and Methodology}

In the Peña Colorada iron-ore deposit, there are two well differentiated zones because of their mineralogical and textural association of magnetite with berthierine and chamosite: (1) magnetite-berthierine intergranular in a stratified orebody; (2) breccia stockwork-type and veins of magnetite with chamosite. 500 samples from both areas were obtained using a systematic sampling and divided in two groups: (1) Base samples, with the representative character of the deposit (mineralogical associations and textural relations); and (2) Samples from metallurgical processes to obtain products such as magnetic and nonmagnetic concentrates. The last ones were separated by density to erase the background produced by the associated minerals, which result in a high proportion of high purity chamosite and berthierine. This purity was controlled by direct optical microscopy, high-quality images were obtained by optical microscopy, XRD and HRTEM.

Base samples and metallurgical products (concentrates) were examined under transmitted and reflected light microscopy using a Leitz SM-LUX-POL polarized microscope. More that 200 thin and polished sections were studied. The optical properties were studied in each separated crystal of chamosite and berthierine using oil immersion. They present refractive index ranging from 1.56 to 1.70 . For identification purposes, shape and orientation were controlled.

The berthierine and chamosite concentrates were analyzed by XRD Simens D-500 using Cu-K $\alpha(\lambda=1.5418$ $\AA$ ) in conditions of $40 \mathrm{kV}$ and $30 \mathrm{~mA}$. Representative base samples and magnetic and non-magnetic concentrates of each type of mineral (berthierine and chamosite) were selected for detailed analysis. The XRD patterns from selected samples were prepared by the standard methods heated at $550^{\circ} \mathrm{C}$ for 1 hour. The purpose was to provoke alteration of the crystalline structure of berthierine and chamosite to corroborate the kaolin-type and chlorite-type structure for berthierine and chamosite, respectively, following the Bailey (1988) method. The kaolin-type structure is characteristic of diagenetic chlorite formed in a marine sedimentary exhalative environment. Polytype identification was according to Bailey (1988) and Carroll (1970).

Representative areas of berthierine and chamosite were selected in the base samples in function of their mode of occurrence and mineral association to be studied by EPMA in order to get their chemical composition. We used a JEOL, 
Table 1. Mineralogical and textural characteristics of berthierine and chamosite.

\begin{tabular}{|c|c|c|c|c|c|c|}
\hline \multirow{2}{*}{$\begin{array}{l}\text { Mineral } \\
\text { Structure } \\
\text { Origin } \\
\text { shape }\end{array}$} & \multicolumn{4}{|c|}{$\begin{array}{c}\text { Berthierine } \\
\text { Stratiform body } \\
\text { Hydrothermal-sedimentary } \\
\end{array}$} & \multicolumn{2}{|c|}{$\begin{array}{c}\text { Chamosite } \\
\text { Mineralized breccia stockwork type } \\
\text { Hydrothermal-epigenetic } \\
\end{array}$} \\
\hline & Microcrystalline & Amorphous & Colloform & Recrystallized & Laminar & $\begin{array}{c}\text { Laminar } \\
\text { with veins }\end{array}$ \\
\hline $\begin{array}{l}\text { Color } \\
\text { size }\end{array}$ & $\begin{array}{l}\text { Dark green } \\
<5 \mu \mathrm{m}\end{array}$ & $\begin{array}{c}\text { Brown-green } \\
0\end{array}$ & $\begin{array}{l}\text { Dark green } \\
<100 \mu \mathrm{m}\end{array}$ & $\begin{array}{l}\text { Bright greenish } \\
\quad<35 \mu \mathrm{m}\end{array}$ & $\begin{array}{l}\text { Olive green } \\
20-200 \mu \mathrm{m}\end{array}$ & $\begin{array}{l}\text { Olive green } \\
15-300\end{array}$ \\
\hline $\begin{array}{l}n^{(I)} \\
\text { Birrefringence }\end{array}$ & $\begin{array}{c}1.64-1.65 \\
0,007\end{array}$ & $\begin{array}{l}1,65 \\
\text { Zero }\end{array}$ & $\begin{array}{c}1.64-1.65 \\
0,007\end{array}$ & $\begin{array}{c}1.64-1.65 \\
\text { Near to } 0.008\end{array}$ & $\begin{array}{c}1.64-1.65 \\
0,008\end{array}$ & $\begin{array}{c}1.64-1.65 \\
0,008\end{array}$ \\
\hline Mineral association & $\begin{array}{l}\text { Botryoidal magnetite, } \\
\text { Siderite, calcite, } \\
\text { organic matter, }\end{array}$ & $\begin{array}{l}\text { Botryoidal magnetite, } \\
\text { calcite, quartz, siderite, } \\
\text { organic matter, sulphides. }\end{array}$ & $\begin{array}{l}\text { Magnetite, siderite, } \\
\text { botryoidal magnetite, } \\
\text { calcite, sulphides. }\end{array}$ & $\begin{array}{l}\text { botryoidal- } \\
\text { Magnetite, } \\
\text { calcite, quartz, }\end{array}$ & $\begin{array}{l}\text { Magnetite massive veins, } \\
\text { feldespars, calcite, quartz, } \\
\text { sericita, epidote, sulphides. }\end{array}$ & $\begin{array}{l}\text { Berthierine and } \\
\text { Magnetite. }\end{array}$ \\
\hline Mode of occurrence & Intergranular matrix. & $\begin{array}{l}\text { Intergranular lining- } \\
\text { in botryoidal magnetite } \\
\text { Intergranular matrix. }\end{array}$ & Colloform banding & $\begin{array}{l}\text { recrystallized- } \\
\text { berthierine } \\
\text { Intergranular- } \\
\text { with magnetite }\end{array}$ & $\begin{array}{l}\text { Open space filling and } \\
\text { replaced the host rocks. }\end{array}$ & $\begin{array}{l}\text { Magnetite,quartz } \\
\text { and berthierine } \\
\text { colloform banding } \\
\text { in veins. }\end{array}$ \\
\hline Figure & $2 a$ & $2 \mathrm{~b}$ & $2, \mathrm{c}, \mathrm{d}$ & $2 \mathrm{e}, \mathrm{f}$ & $8 \mathrm{a}, \mathrm{b}, \mathrm{c}$. & $8 \mathrm{~d}$ \\
\hline
\end{tabular}

(1) $R$ efraction index.

Table 2. Representative multielemental analyses (wt \%) and structural formulae of berthierine.

\begin{tabular}{|c|c|c|c|c|c|c|c|c|c|}
\hline \multirow{3}{*}{$\begin{array}{l}\text { Ocurrencia } \\
\text { Polytype } \\
\text { Origin } \\
\text { Sample No. }\end{array}$} & \multicolumn{5}{|c|}{ Intergranular } & \multirow{3}{*}{\multicolumn{2}{|c|}{$\begin{array}{c}\text { Colloform banding } \\
\mathrm{I} b \\
\text { Hidrothermal-Sed }\end{array}$}} & \multirow{2}{*}{\multicolumn{2}{|c|}{$\begin{array}{c}\text { Recrystallized } \\
\text { Ilb } \\
\text { High grade-diagenetic }\end{array}$}} \\
\hline & \multirow{2}{*}{\multicolumn{2}{|c|}{ A -3}} & \multirow{2}{*}{\multicolumn{2}{|c|}{$\begin{array}{c}\mathrm{I} b \\
\text { ermal-sedimentary } \\
\text { A - } 309\end{array}$}} & \multirow{3}{*}{$\frac{\mathrm{A}-318}{23,72}$} & & & & \\
\hline & & & & & & & & & $\begin{array}{l}\text { genetic } \\
\text { A - 31D }\end{array}$ \\
\hline $\mathrm{SiO} 2$ & 30,47 & 30,52 & 29,03 & 29,31 & & 28,39 & 30,30 & 27,45 & 24,25 \\
\hline $\mathrm{TiO} 2$ & 0,02 & 0,04 & 0,00 & 0,01 & 0,00 & 0,32 & 0,00 & 0,00 & 0,00 \\
\hline $\mathrm{Al} 2 \mathrm{O} 3$ & 14,85 & 15,27 & 14,38 & 14,20 & 17,62 & 14,60 & 18,25 & 18,11 & 26,29 \\
\hline $\mathrm{FeO}$ & 45,70 & 46,61 & 47,16 & 48,06 & 44,55 & 46,07 & 32,66 & 40,03 & 35,90 \\
\hline $\mathrm{MnO}$ & 0,46 & 0,51 & 0,48 & 0,52 & 0,00 & 0,44 & 0,00 & 0,00 & 3,01 \\
\hline $\mathrm{MgO}$ & 4,99 & 5,01 & 6,02 & 5,98 & 7,66 & 4,69 & 6,36 & 7,82 & 5,11 \\
\hline $\mathrm{CaO}$ & 0,47 & 0,28 & 0,18 & 0,15 & 0,00 & 0,29 & 0,00 & 0,70 & 0,01 \\
\hline $\mathrm{Na} 2 \mathrm{O}$ & 0,05 & 0,02 & 0,02 & n. d. & 0,00 & 0,02 & 0,00 & 0,00 & 0,03 \\
\hline $\mathrm{K} 2 \mathrm{O}$ & 0,07 & 0,10 & 0,01 & 0,05 & 0,00 & 0,17 & 0,00 & 0,00 & 0,01 \\
\hline $\mathrm{Cl}$ & n. d. & n. d. & n. d. & 0,10 & 0,00 & n. d. & 0,00 & 0,00 & 0,28 \\
\hline $\mathrm{Cr} 2 \mathrm{O} 3$ & 0,04 & n. d. & 0,03 & n. d. & 0,00 & 0,01 & 0,00 & 0,33 & 0,05 \\
\hline \multirow[t]{2}{*}{$\mathrm{NiO}$} & n. d. & n. d. & n. d. & n. d. & 0,00 & 0,01 & 0,00 & 2,90 & 0,00 \\
\hline & 97,12 & 98,35 & 97,31 & 98,37 & 0,00 & 94,99 & 87,57 & 97,34 & 94,94 \\
\hline $\mathrm{Si}$ & 6,345 & 6,291 & 6,113 & 6,120 & 5,981 & 5,913 & 5,737 & 5,652 & 4,978 \\
\hline${ }^{\mathrm{IV}} \mathrm{Al}$ & 1,655 & 1,709 & 1,887 & 1,880 & 2,02 & 2,087 & 2,263 & 2,348 & 3,022 \\
\hline${ }^{\mathrm{vi}_{\mathrm{Al}} \mathrm{Al}}$ & 2,006 & 2,013 & 1,692 & 1,629 & 2,236 & 1,514 & 1,837 & 2,062 & 3,381 \\
\hline $\mathrm{Ti}$ & 0,002 & 0,007 & n. d. & 0,002 & 0,000 & 0,505 & 0 & 0,000 & 0,000 \\
\hline $\mathrm{Cr}$ & 0,006 & n. d. & 0,006 & n. d. & 0,000 & 0,001 & 0 & 0,054 & 0,008 \\
\hline $\mathrm{Fe} 3+$ & 0,187 & 0,164 & n. d. & n. d. & 0,121 & 0,223 & 0 & 0,000 & 0,256 \\
\hline $\mathrm{Fe} 2+$ & 7,772 & 7,872 & 8,388 & 8,479 & 7,233 & 7,802 & 9,219 & 6,989 & 5,907 \\
\hline $\mathrm{Mn}$ & 0,081 & 0,088 & 0,085 & 0,091 & 0,000 & 0,078 & 0 & 0,000 & 0,524 \\
\hline $\mathrm{Mg}$ & 1,550 & 1,540 & 1,889 & 1,860 & 2,254 & 1,456 & 1,186 & 2,400 & 1,563 \\
\hline $\mathrm{Ni}$ & n. d. & n. d. & n. d. & 0,001 & 0,000 & 0,001 & 0 & 0,480 & 0,000 \\
\hline $\mathrm{Ca}$ & 0,104 & 0,061 & 0,041 & 0,034 & 0,000 & 0,065 & 0 & 0,154 & 0,002 \\
\hline $\mathrm{Na}$ & 0,040 & 0,016 & 0,016 & 0,000 & 0,000 & 0,012 & 0 & 0,000 & 0,021 \\
\hline K & 0,038 & 0,050 & 0,006 & 0,024 & 0,000 & 0,091 & 0 & 0,000 & 0,006 \\
\hline $\mathrm{Cl}$ & n. d. & n. d. & n. d. & 0,071 & 0,000 & n. d. & 0 & 0,000 & 0,191 \\
\hline \multirow[t]{2}{*}{$\mathrm{OH}^{*}$} & 16,000 & 16,000 & 16,000 & 15,929 & 16,000 & 16,000 & 16 & 16,000 & 15,809 \\
\hline & 35,786 & 35,812 & 36,123 & 36,120 & 35,845 & 35,748 & 36,264 & 36,139 & 35,669 \\
\hline $\mathrm{Al}_{\text {Total }}$ & 3,661 & 3,722 & 3,580 & 3,509 & 4,255 & 3,601 & 4,1 & 4,410 & 6,403 \\
\hline $\mathrm{Fe}_{\text {Total }}$ & 7,959 & 8,036 & 8,388 & 8,479 & 7,354 & 7,88 & 9,219 & 6,989 & 6,163 \\
\hline $\mathrm{Fe} /(\mathrm{Fe}+\mathrm{Mg})$ & 0,83 & 0,84 & 0,82 & 0,82 & 0,77 & 0,85 & 0,74 & 0,744 & 0,798 \\
\hline $\mathrm{Fe}+\mathrm{Mg}+\mathrm{Mn}$ & 8,04 & 8,12 & 8,47 & 10,43 & 9,608 & 9,55 & 10,405 & 9,389 & 7,766 \\
\hline Oct. & 11,786 & 11,811 & 12,123 & 12,12 & 11,844 & 11,748 & 12,242 & 12,139 & 11,668 \\
\hline $\mathrm{Al} / \mathrm{Si}$ & 0,6 & 0,6 & 0,6 & 0,6 & 0,7 & 0,6 & 0,714 & 0,8 & 1,3 \\
\hline $\mathrm{Mg} / \mathrm{Fe}$ & 0,19 & 0,19 & 0,22 & 0,22 & 0,31 & 0,18 & 0,13 & 0,34 & 0,25 \\
\hline $\mathrm{M}: \mathrm{Or}^{(1)}$ & Or & Or & Or & Or & Or & Or & Or & M Or & $\mathrm{M}$ \\
\hline
\end{tabular}

${ }^{(1)}$ M:Or signifies ratio of $\mathrm{M}$ (monoclinic) to Or (orthorhombic) form.

JXA $8900-\mathrm{R}$ microscope, with $20 \mathrm{Kv}$ acceleration voltage and $20 \mathrm{sec}$ acquisition time. The electron-microprobe analyses used the standards SPI\#02753-AB.

Mössbauer spectroscopy analyses of berthierine and chamosite were completed in order to obtain details of their chemical characteristics. The Mössbauer spectra were obtained at room temperature with a constant acceleration transducer and 512 multichannel analyzer: the velocity calibration was performed with a laser interferometer referred to metallic iron, -source of ${ }^{57} \mathrm{Co} / \mathrm{Rh}$.

The High Resolution Transmission Electron Microscope (HRTEM) studies were completed using a JEOL 2010 FEG FASTEM, with a spherical aberration coefficient of $C_{s}=0.5$ $\mathrm{nm}$ and a point resolution $\approx 1.94 \AA$ at an acceleration voltage of $200 \mathrm{kV}$. This offers a resolution better than $0.2 \mathrm{~nm}$ and allows analysis of nanometer-order specimen areas.

\section{Ocurrence of Berthierine and Chamosite}

Chamosite and berthierine are minerals of limited occurrence in nature, and important components in the ironore deposit of Peña Colorada. By virtue of their composition, texture, and mineralogical associations, chamosite and berthierine could act out as a record of the chemical and physical conditions existing during the iron-ore genesis. Thus, we can understand the origin, environment of deposition, hydrothermal alteration, and metamorphism that occurred in the Peña Colorada deposit. Berthierine is clearly differentiated from chamosite because its dark green to brown color, microcrystalline to amourphous shape, and very low $(<0.007)$ to null birefringence. The main miner- 

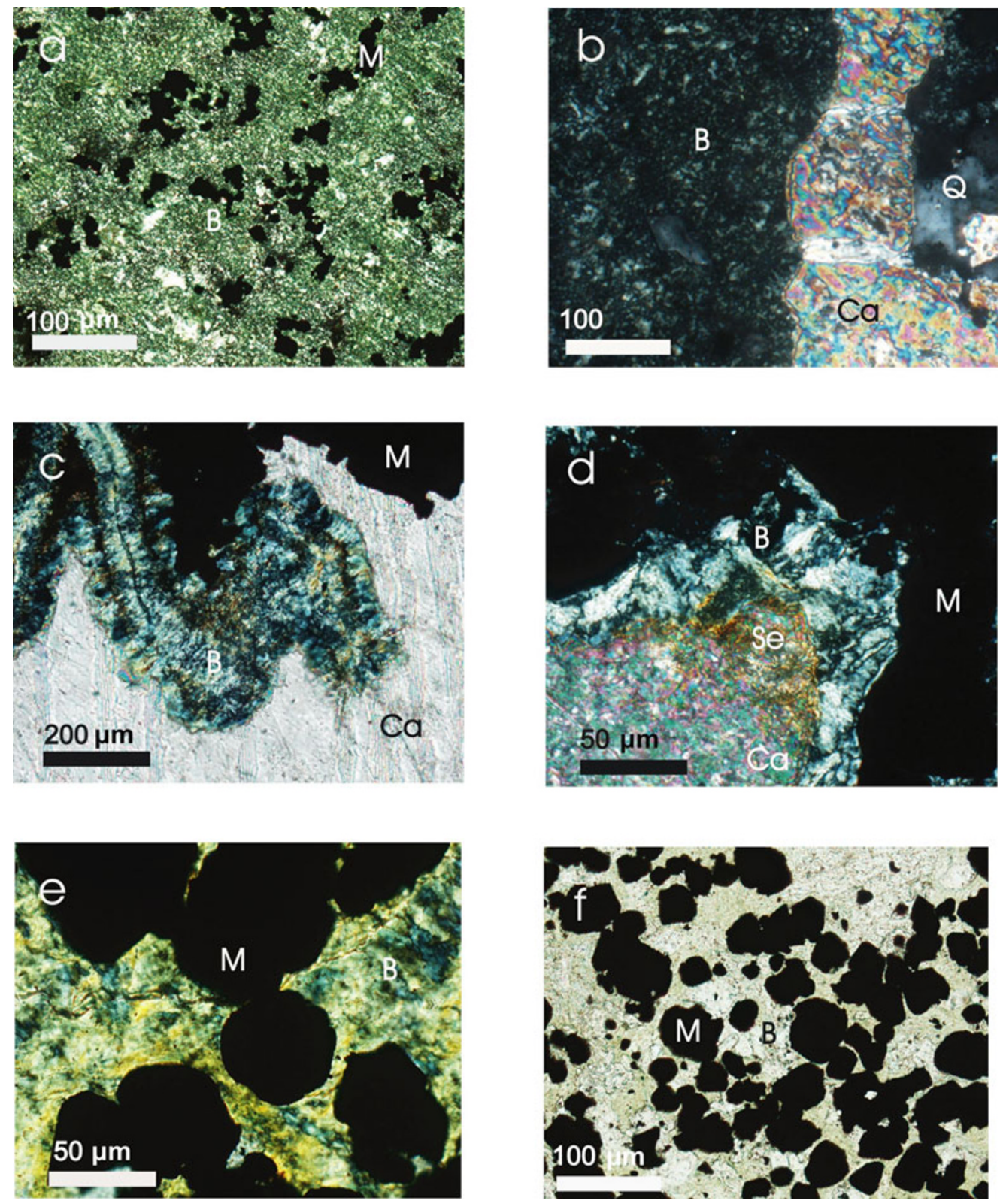

Fig. 2. Optical microscope microphotographs of the berthierine: (a) Microcrystalline berthierine (B) of A-3 sample forming an intergranular matrix with magnetite (M); (b) Amorphous berthierine showing microcrystalline areas forming intergranular texture with magnetite, sample A-309. Amorphous berthierine clearly shows null birefringency (isotropy). Quartz veins $(\mathrm{Q})$ and calcite $(\mathrm{Ca})$ cut the berthierine; (c) Colloform bands berthierine of sample A-46 in contact with magnetite and calcite; (d) Colloform berthierine along the borders of magnetite, associated to siderite (Se) and calcite (sample A-46); (e) Botryoidal magnetite in intergranular berthierine matrix partly recrystallized (sample A-MM-5); (f) Magnetite-berthierine of intergranular texture (sample A-38).

alogical and textural characteristics of the berthierine and chamosite are reported in Table 1.

\subsection{Berthierine}

The berthierine belongs to the chlorite group. It is a phyllosilicate chemically and closely related to chorites, but structurally related to serpentine. It has a layered structure, each layer having a tetrahedral $(\mathrm{Si}, \mathrm{Al})_{2} \mathrm{O}_{5}$ component, and linked to a tri-octahedral (brucite-type) component (Deer, 1993). This latter component is similar to ferriferrous clay mineral (Bhattacharyya, 1983). The general composition of berthierine is $\mathrm{Y}_{6} \mathrm{Z}_{4} \mathrm{O}_{10}(\mathrm{OH})_{8},\left(\mathrm{Y}=\mathrm{Fe}^{2+}, \mathrm{Mg}, \mathrm{Fe}^{3+}, \mathrm{Al}\right.$; $\mathrm{Z}=\mathrm{Si}, \mathrm{Al}, \mathrm{Fe}_{+3}$ ) (Bhattacharyya, 1983). Berthierine has Fe-Al, 1:1- type layer silicate with basal spacing of $7 \AA$ (Damyanov and Vassileva, 2001).
3.1.1 Optical microscopy Berthierine has very fine microcrystalline to amorphous grain size. It is present in three varieties depending of its texture and mineralogical associations (Fig. 2): (1) berthierine-magnetite intergranular; (2) berthierine in colloform banding and open space filling; (3) berthierine recrystallized. Berthierine is distinguished of chamosite because of its intense dark green and brown color along the magnetite contact. It markedly shows pleochroism from greenish yellow to grass green, the interference tints are masked by the mineral color. It has a high refraction index from 1.64 to 1.65 and birefringence ranging from 0.007 to zero. Berthierine is mainly associated to magnetite and in minor proportion to sulfides (pyrite and chalcopyrite), siderite, calcite, quartz and organic mat- 
ter. Opaque minerals as magnetite and sulfur were fully studied and corroborated by optical microscopy using reflected light, XRD and SEM with multielemental analyses (EPMA).

3.1.2 X-ray difraction (XRD) We analyzed pure berthierine samples coming from intergranular, colloform banding, open space filling, and recrystallized berthierine. Figure 3 shows this three typical XRD patterns of berthierine. The spectra of the diffraction pattern (and structure) are similar to the disordered kaolinite with a lower degree of structural ordering. It does not show the reflection $d=14.4$ A.

We carried out new tests to prove the identification of berthierine. It consists in altering their structure following the Carroll (1970) procedure. Samples were calcined at $550^{\circ} \mathrm{C}$ over one hour, after that the residues were analyzed by XRD. In the acquired spectra, the reflections disappeared showing amorphous spectrums (Fig. 3). Carroll (1970) indicates that kaolin-type chlorite gives a diffraction pattern and a heating pattern similar to kaolinite. That is, the kaolin-type structure collapses by heating at $\sim 550^{\circ} \mathrm{C}$ and the diffraction pattern appears amorphous.

The variation of chemical composition in chlorite produce structures called polytypes (Bailey and Brown, 1962; Bailey, 1988, 1991). They report structures in the form of layers similar to mica, which has structural arrangements in brucite-type layers (tri-octahedral component in the network). They recognized that $80 \%$ of the chlorites are the II $b$ polytype in which the structure is a monoclinic unit cell. The chlorite residual is the $\mathrm{I} b$ polytype based on an orthohexagonal (or orthorhombic) unit cell (Carroll, 1970). Berthierine belongs to this one.

Berthierine has a higher content of $\mathrm{FeO}$ and a crystal structure similar to kaolin (orthorhombic). The biggest reflection, equivalent to $100 \%$ is $d_{h k l}=7 \AA$ [001] as occuring in kaolin. Polytypes are in the function of the composition of sheets and not of the sequence of accommodation in the mineral. Berthierine shows $\mathrm{I} b$ polytype in base to its composition, radicals $\mathrm{R}^{+3}$ replacing $\mathrm{Al}$ and $\mathrm{Si}$, predominating an octahedral unit cell.

3.1.3 Mineral chemistry Results of the representative microprobe analyzes in wt.\% and structural formulae are presented in Table 2. A Berthierine formulae unit was calculated on the basis of 28 oxygens and with $\mathrm{Fe}^{2+} / \mathrm{Fe}^{3+}$ and $\mathrm{OH}$ calculated assuming full site occupancy. It is notable that the major content of $\mathrm{FeO}$ ranges from 32 to $48 \%$. $\mathrm{SiO}_{2}$ is between 28 to $30 \%$, decreasing to $24 \%$ in berthierine samples that are affected by high-degree diagenetic. Content of $\mathrm{MgO}$ is low (4 a 7\%). $\mathrm{CaO}, \mathrm{Na} 2 \mathrm{O}, \mathrm{K}_{2} \mathrm{O}, \mathrm{Ca}_{2} \mathrm{O}_{3}$ and $\mathrm{MnO}$ is also low $<0.7 \%$. $\mathrm{TiO}_{2}$ was undetected in most samples, and is $<0.04 \%$ when present.

The content of $\mathrm{H}_{2} \mathrm{O}$ is total and does not make any difference between $\mathrm{H}_{2} \mathrm{O}+\mathrm{y} \mathrm{H}_{2} \mathrm{O}$-. Octahedral cations are in the range 0.74 to 0.85 , reaching up to 3.0 in metamorphosed samples. The tetrahedral $\mathrm{Al}$ cation is in the range from $x=1.6$ to 2.3 atoms per formulae unit.

The three types of berthierine differ in their chemical composition (Table 2). The intergranular berthierine has low Al content and more vacant octahedral positions than colloform banding and open space filling berthierine.

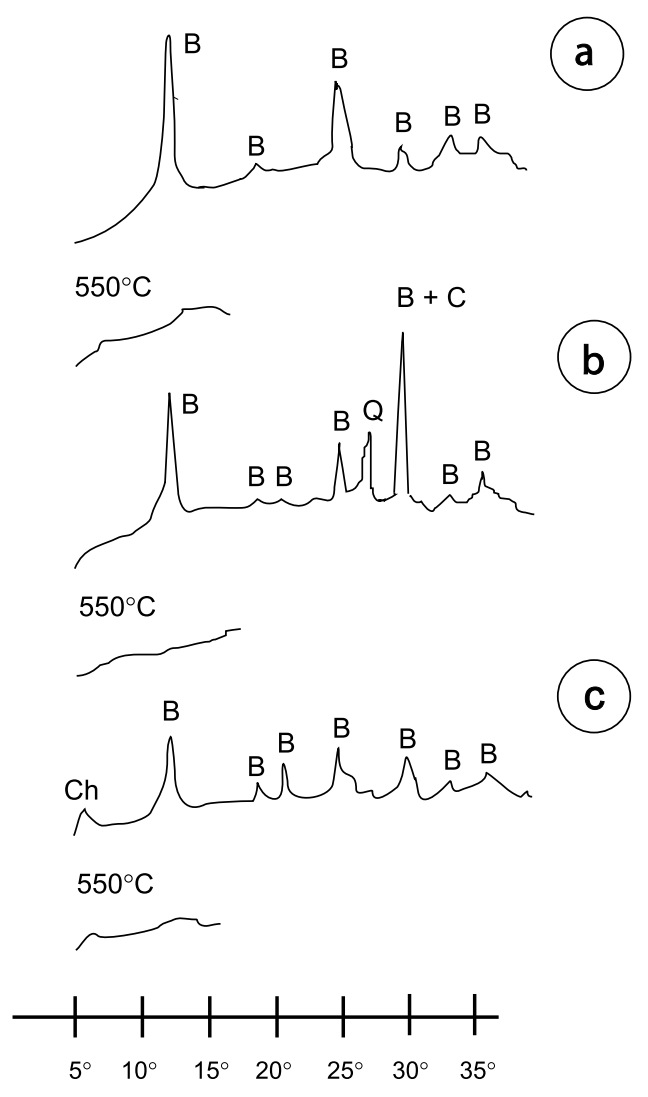

Fig. 3. XRD patterns of berthierine (B) in distinct textural modes from samples heated at $550^{\circ} \mathrm{C}$. (a) Intergranular berthierine of the $\mathrm{Ib}\left(\beta=90^{\circ}\right)$ group. It shows the characteristic spectrum of samples with low degree of structural ordering. (b) Berthierine in colloform banding and open space filling of the $\mathrm{Ib}\left(\beta=90^{\circ}\right)$ group, and (c) Berthierine recrystallized to chamosite $(\mathrm{Ch})$ for high-degree diagenetic or low-degree metamorphic of the II $b$ polytype. C: calcite, Q: quartz.

The compositional variation in the intergranular magnetiteberthierine is greater than the berthierine present in the high-degree diagenetic zone. This latter is considerably more homogenous and structurally well balanced. Content of $\mathrm{Si}$ replaced by $\mathrm{Al}$ keep a 1:2 proportion.

Two triangular diagrams are utilized: (1) $\mathrm{Fe}+\mathrm{Mg}+\mathrm{Mn}$ - Si - Al and (2) Mg - Fe - Al. Both diagrams show the composition of berthierine. They indicate the trend of atom numbers per formulae unit functioning in a distinct environment and depositional conditions.

3.1.4 High Resolution Transmission Electron Microscope (HRTEM) The crystalline structure of berthierine is formed by packages ordered in parallel form. Some layers are deformed and in other fields the structure is surrounded by an amorphous phase which supports the XRD results. In this amorphous phase are located the botryoidal micro- and nanoparticles of magnetite (Fig. 4). Those particles were identified by HRTEM defining the main interplanar distances of magnetite with values $d_{h k l}=3.06 \AA$ [220], $2.56 \AA$ [311] (Rivas-Sanchez et al., in prep.).

The interplanar distance corresponds to the values: $d_{h k l}=7 \AA\left[\begin{array}{lll}0 & 0 & 1\end{array}\right], 3.52\left[\begin{array}{lll}0 & 0 & 2\end{array}\right], 4.3\left[\begin{array}{lll}1 & 0 & 0\end{array}\right]$ and 2.5 [ [ lll 111$]$ (Figs. 5 and 6). Diffraction patterns support the suggested interplanar distances. The angle measurements from the Fast Fourier Transform show an hexagonal type crystalline 


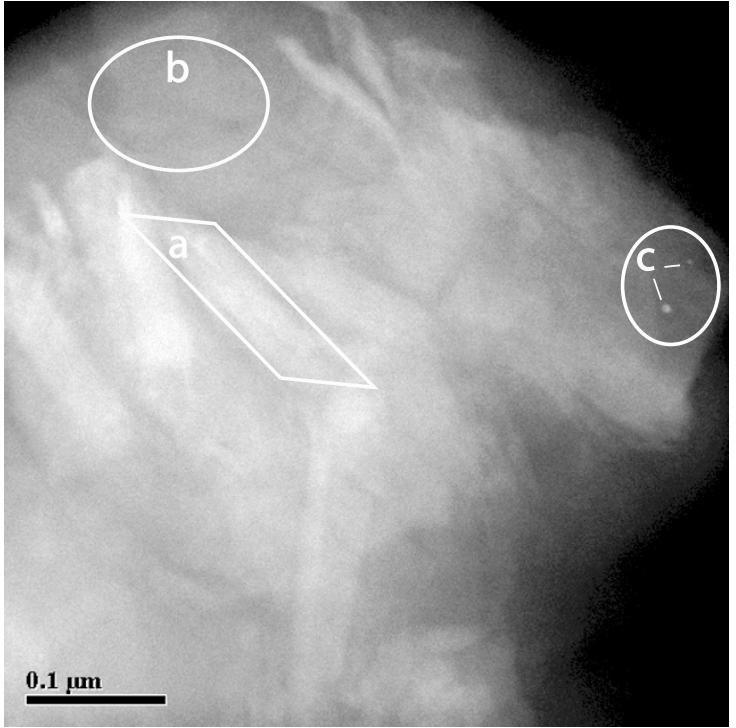

Fig. 4. High resolution (HRTEM) image obtained from sample A-3. (a) Crystalline structure of berthierine arranged in packages forming parallel layers surrounded by an amorphous phase with null to low degree of estructural ordering. (b) Amorphous phase berthierine. (c) Magnetite nanopartículas distributed in the amorphous phase of berthierine.

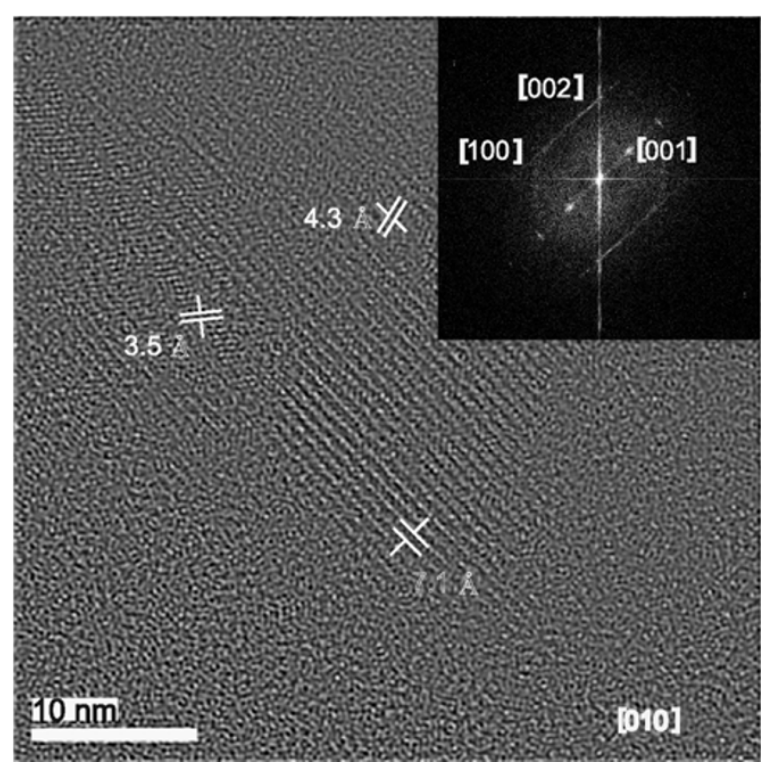

Fig. 5. High resolution (HRTEM) image obtained from sample A-3. Crystalline structure of berthierine showing interplanar distances corresponding to the values $d_{h k l}=7.1 \AA$ [001], $3.5 \AA$ [002] and $4.3 \AA$ [100]. Inset, FFT images indicates that the berthierine is orientated in [001] direction.

structure (Fig. 5) that corresponds to an orthorhombic unit cell (Brindley and Youell, 1953) or to a trigonal unit cell (Brindley, 1951).

3.1.5 Mössbauer spectroscopy The study of berthierine shows quadrupolar unfolding typical of two states of oxidation; $\mathrm{FeO}$ and $\mathrm{Fe}_{2} \mathrm{O}_{3}$ (Fig. 7).

\subsection{Chamosite}

The chamosite structure is very similar to typical chlorite in which there are alternated regular layers with tetrahedral and tri-octahedral components. Its 2:1 layer structure is similar to that of mica, with a basal spacing of $14 \AA$. The

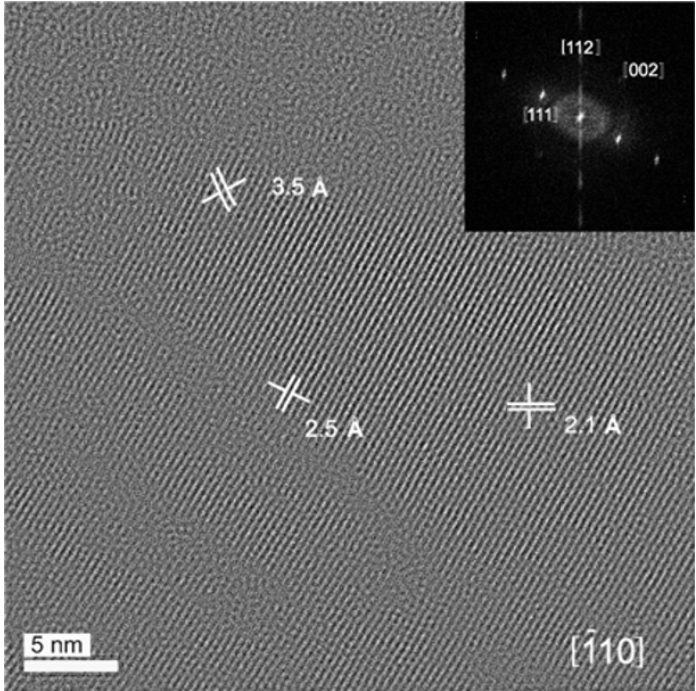

Fig. 6. High resolution (HRTEM) image obtained from sample A-3. Berthierine structure showing the interplanar distances corresponding to values $d_{h k l}=2.5 \AA$ [111] and $3.5 \AA$ [002]. Inset, FFT image suggests that berthierine is oriented in [111] direction.

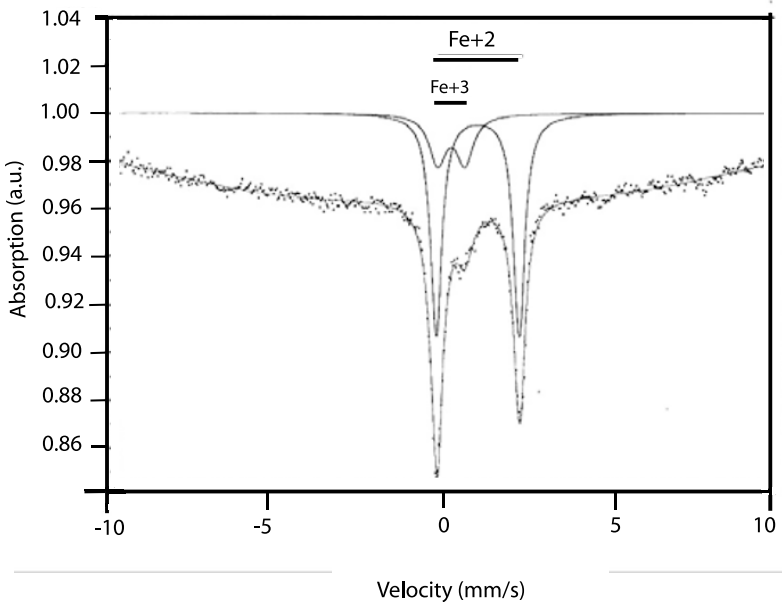

Fig. 7. Mössbauer spectroscopy apectrum showing the typical quadrupolar unfolding of two oxidation states: $\mathrm{FeO}$ and $\mathrm{Fe} 2 \mathrm{O}_{3}$.

general composition is $(\mathrm{Mg}, \mathrm{Fe}, \mathrm{Al})_{6}(\mathrm{Al}, \mathrm{Si})_{4} \mathrm{O}_{10}(\mathrm{OH})_{8}$. $\mathrm{Fe}_{2}$ is the dominant composite, $\mathrm{Al}$ is in lower proportion, and $\mathrm{Mg}$ and $\mathrm{Si}$ are slightly higher.

The formation of polytypes is due to the equilibrium of the available energy in the environment. Chlorite is formed, in stable conditions, as a result of low-degree metamorphism under medium to high-temperature and it is II $b$ polytype.

3.2.1 Optical microscopy Chamosite has a laminar shape, sheets measure from 20 to $200 \mu \mathrm{m}$ (Fig. 8). Two types of chamosite were observed, based on its texture and mode of occurrence: (1) open space filling chamosite; and (2) chamosite with veins of colloform banding of berthierine. Chamosite is associated with the host rock, generally completely replacing feldspar hornfels through veins and fractures, altered rocks, and low-degree metamorphism. It represents the beginning of the hydrothermal phase. 

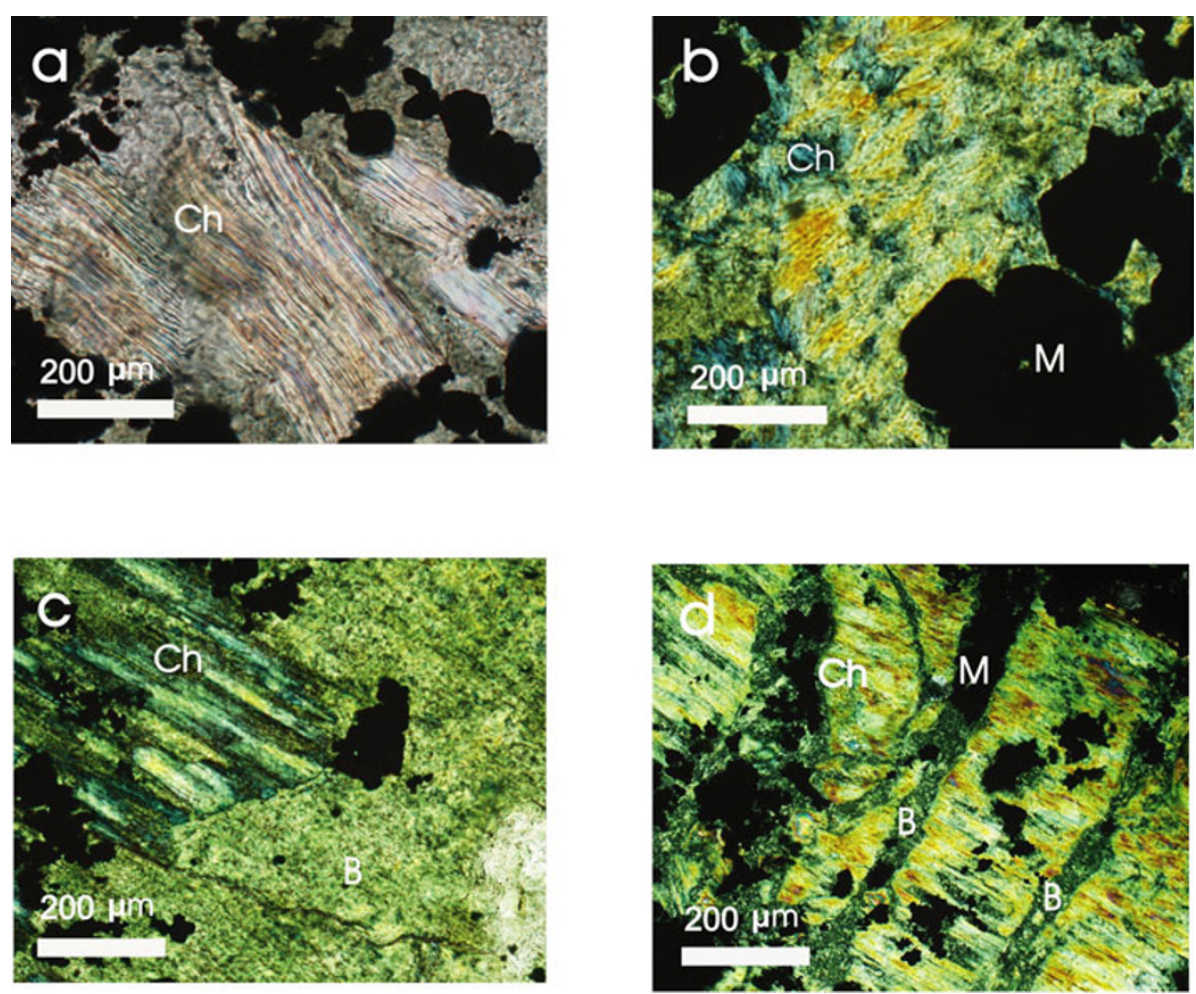

Fig. 8. Optical microscope microphotographs of the chamosite. (a) Lamellar chamosite. (b) Chamosite replacing the host rock and filling open spaces in magnetite (M). (c) Chamosite lamella partly replaced by berthierine (B) along its borders. d) Lamellar chamosite with berthierine veins and magnetite.

Chamosite is distinguished because of its olive green color with remarkable pleochroism from greenish to light green. It has a high index refraction (1.64-1.65). Its birefringence is low, near 0.008 (Fig. 8). Orientation is Biaxial (-) with a $2 \mathrm{~V}$ small. The cleavage are length-slow, the orientation may be $\alpha \wedge c=$ small, $\beta=\mathrm{b}, \gamma \wedge \alpha=$ small, optic plane $=\left[\begin{array}{ll}0 & 1\end{array}\right.$ 0] (Heinrich, 1965).

3.2.2 X-Ray diffraction The chamosite spectra shows the reflection $d=7.18 \AA$ (main value of the chlorite) and the reflection $d=14.4 \AA$ (that confirms the presence of chlorite) (Fig. 9). Using the heating method (Brindley, 1961; Carroll, 1970), we observed that chamosite did not collapse at $550^{\circ} \mathrm{C}$, the chlorite value $d=14 \AA$ increased, and $d=7 \AA$ decreased (Fig. 9). Thus, the order of refraction intensity is different. Chamosite with a similar structure to typical chlorite does not collapse at $550^{\circ} \mathrm{C}$. However, there are changes in the intensity of the values of the main reflection, like value $d=7.18 \AA(100 \%)$, that appears to be smaller with respect to the secondary reflection $d=14.2 \AA$ (70\%).

3.2.3 Mineral chemistry Results of representative microprobe analyses in \% wt and the structural formulae are presented in Table 3. Chamosite formulae units were used on the basis of 28 oxygens and with $\mathrm{Fe}^{2+} / \mathrm{Fe}^{3+}$ and $\mathrm{OH}$, calculated assuming full-site occupancy. Chamosite has an important amount of $\mathrm{Fe}$ ranging from 23 to $39 \%$. $\mathrm{SiO}_{2}$ remains decreasing between 26 and $35 \%$. The $\mathrm{MgO}$ content is high, ranging from 11 to $20 \%$, and $\mathrm{Fe} 2 \mathrm{O}_{3}, \mathrm{Na} 2 \mathrm{O}, \mathrm{K}_{2} \mathrm{O}$ and $\mathrm{MnO}$ are low $<2 \%$. $\mathrm{TiO}_{2}$ was undetected in most samples, and is $<0.2 \%$ when present.

The content of $\mathrm{H}_{2} \mathrm{O}$ is total and does not make any dif-

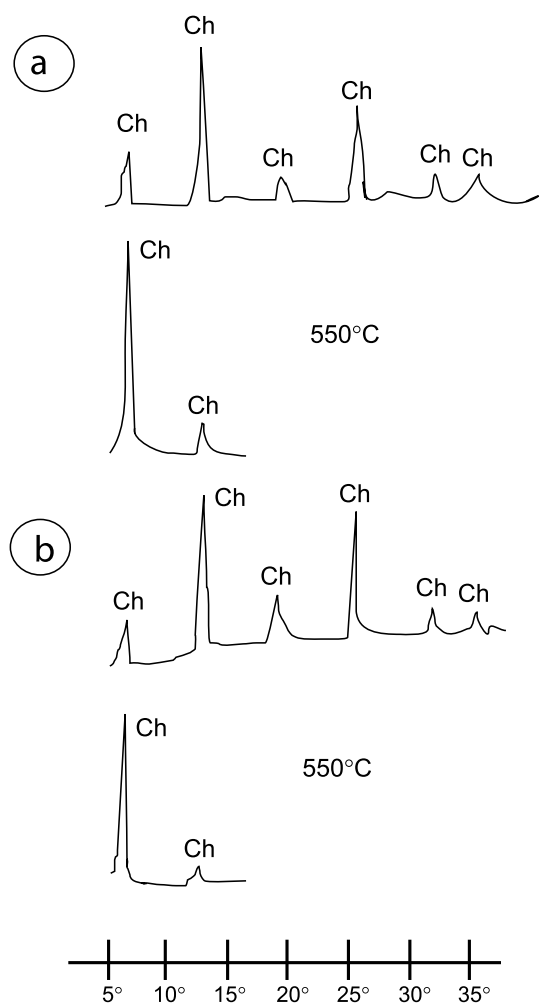

Fig. 9. XRD patterns of chamosite in distinct textural modes and mineralogical association from samples heated at $550^{\circ} \mathrm{C}$. (a) $\mathrm{II} b$ polytype lamellar chamosite shows a characteristic spectrum with a high degree of structural ordering. (b) Lamellar chamosite with berthierine veins. Berthierine replaces chamosite through fractures following a replacement front. 
Table 3. Representative multielemental analyses (wt $\%$ ) and structural formulae of chamosite.

\begin{tabular}{|c|c|c|c|c|c|c|c|}
\hline \multirow{3}{*}{$\begin{array}{l}\text { Shape } \\
\text { Polytype } \\
\text { Origin } \\
\text { Sample No. } \\
\end{array}$} & \multicolumn{5}{|c|}{ Laminar } & \multicolumn{2}{|c|}{ Replaced for berthierine } \\
\hline & \multicolumn{5}{|c|}{$\begin{array}{c}\text { Ilb } \\
\text { Hydrothermal-epigenetic } \\
\text { N - } 239\end{array}$} & \multicolumn{2}{|c|}{$\begin{array}{c}\mathrm{Ilb} \\
\text { Hydrothermal } \\
\mathrm{N}-3\end{array}$} \\
\hline & 29,37 & 27,40 & 29,44 & 29,72 & 33,31 & 35,29 & 26,19 \\
\hline $\mathrm{TiO} 2$ & 0,00 & 0,00 & 0,03 & 0,29 & 0,00 & 0,01 & 0,00 \\
\hline $\mathrm{Al} 2 \mathrm{O} 3$ & 17,95 & 16,20 & 15,68 & 16,53 & 13,81 & 17,23 & 15,67 \\
\hline $\mathrm{FeO}$ & 28,66 & 39,39 & 36,72 & 37,40 & 31,78 & 23,38 & 27,20 \\
\hline $\mathrm{MnO}$ & 1,15 & 0,00 & 1,63 & 1,32 & 1,93 & 1,11 & 1,20 \\
\hline $\mathrm{MgO}$ & 17,44 & 11,19 & 12,42 & 12,17 & 12,48 & 20,48 & 12,76 \\
\hline $\mathrm{CaO}$ & 0,44 & 0,00 & 1,49 & 0,25 & 3,15 & 2,66 & 0,39 \\
\hline $\mathrm{Na} 2 \mathrm{O}$ & 0,00 & 0,00 & 0,04 & 0,00 & 0,00 & 0,10 & 1,02 \\
\hline $\mathrm{K} 2 \mathrm{O}$ & 0,00 & 0,00 & 0,18 & 0,05 & 0,00 & 0,00 & 0,01 \\
\hline $\mathrm{ZnO}$ & 0,00 & 0,00 & 0,51 & 0,58 & 1,26 & 0,00 & 0,00 \\
\hline $\mathrm{Cl}$ & 0,44 & 0,00 & 0,76 & 0,77 & 0,66 & 0,00 & 0,58 \\
\hline $\mathrm{Cr} 2 \mathrm{O} 3$ & 0,00 & 0,00 & 0,25 & 0,00 & 0,02 & 0,01 & 0,00 \\
\hline \multirow[t]{2}{*}{$\mathrm{NiO}$} & 0,00 & 0,00 & 0,85 & 0,00 & 0,00 & 0,01 & 0,72 \\
\hline & 95,45 & 94,18 & 100 & 99,08 & 98,40 & 100,28 & 85,74 \\
\hline $\mathrm{Si}$ & 5,753 & 5,719 & 5,762 & 5,872 & 5,839 & 6,348 & 6,385 \\
\hline${ }^{\mathrm{iv}} \mathrm{Al}$ & 2,25 & 2,281 & 2,238 & 2,128 & 2,161 & 1,652 & 1,615 \\
\hline $\mathrm{v}_{\mathrm{Al}} \mathrm{l}$ & 1,917 & 1,737 & 1,427 & 1,74 & 2,01 & 2,016 & 2,190 \\
\hline $\mathrm{Ti}$ & 0,000 & 0,00 & 0,004 & 0,043 & 0,00 & 0,001 & 0,007 \\
\hline $\mathrm{Cr}$ & 0,000 & 0,000 & 0,039 & 0,00 & 0,00 & 0,001 & 0,00 \\
\hline $\mathrm{Fe} 3+$ & 0,000 & 0,000 & 0 & 0,002 & 0,061 & 0,190 & 0,16 \\
\hline $\mathrm{Fe} 2+$ & 4,758 & 7,101 & 6,178 & 6,178 & 5,061 & 3,327 & 4,596 \\
\hline $\mathrm{Mn}$ & 0,190 & 0,000 & 0,27 & 0,221 & 0,315 & 0,169 & 0,213 \\
\hline $\mathrm{Mg}$ & 5,091 & 3,48 & 3,624 & 3,59 & 3,59 & 5,49 & 3,980 \\
\hline $\mathrm{Zn}$ & 0,000 & 0,00 & 0,074 & 0,09 & 0,18 & 0,00 & 0,000 \\
\hline $\mathrm{Ni}$ & 0,000 & 0,000 & 0,134 & 0,000 & 0,00 & 0,001 & 0,009 \\
\hline $\mathrm{Ca}$ & 0,093 & 0 & 0,313 & 0,053 & 0,65 & 0,514 & 0,087 \\
\hline $\mathrm{Na}$ & 0,003 & 0,000 & 0,031 & 0,000 & 0,000 & 0,068 & 0,83 \\
\hline $\mathrm{K}$ & 0,000 & 0,000 & 0,091 & 0,024 & 0,000 & 0,001 & 0,004 \\
\hline & 0,290 & 0,00 & 0,657 & 0,52 & 0,431 & 0,00 & 0,046 \\
\hline \multirow[t]{2}{*}{$\mathrm{OH}^{*}$} & 15,710 & 16,000 & 15,343 & 15,484 & 15,569 & 16,000 & 15,954 \\
\hline & 36,052 & 36,320 & 36,185 & 35,932 & 35,860 & 35,778 & 36,079 \\
\hline $\mathrm{Al}_{\mathrm{T}_{\text {otal }}}$ & 4,165 & 4,018 & 3,665 & 3,869 & 4,166 & 3,668 & 3,805 \\
\hline $\mathrm{Fe}_{\text {Total }}$ & 4,758 & 7,101 & 6,178 & 6,18 & 5,122 & 3,517 & 4,759 \\
\hline $\mathrm{Fe} /(\mathrm{Fe}+\mathrm{Mg})$ & 0,48 & 0,671 & 0,63 & 0,63 & 0,59 & 0,39 & 0,545 \\
\hline $\mathrm{Fe}+\mathrm{Mg}+\mathrm{Mn}$ & 10,039 & 10,582 & 10,071 & 9,984 & 9,022 & 9,176 & 7,997 \\
\hline Oct. & 12,052 & 12,318 & 12,185 & 11,908 & 11,86 & 11,778 & 12,076 \\
\hline $\mathrm{Al} / \mathrm{Si}$ & 0,7 & 0,7 & 0,6 & 0,7 & 0,8 & 0,58 & 0,6 \\
\hline$\underline{\mathrm{Mg} / \mathrm{Fe}}$ & 1,07 & 0,49 & 0,59 & 0,58 & 0,75 & 1,56 & 0,84 \\
\hline $\mathrm{M}: \mathrm{Or}^{(1)}$ & $\mathrm{M}$ & $\mathrm{M}$ & $\mathrm{M}$ & $\mathrm{M}$ & $\mathrm{M} \sim \mathrm{Or}$ & $\mathrm{Or}>\mathrm{M}$ & Or>M \\
\hline
\end{tabular}

${ }^{11} \mathrm{M}$ :Or signifies ratio of $\mathrm{M}$ (monoclinic) to Or (orthorhombic) form.

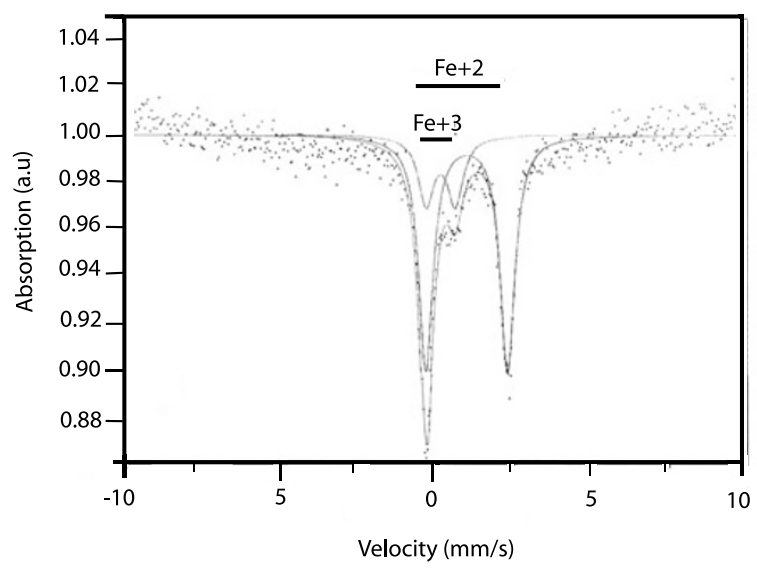

Fig. 10. Mössbauer spectra showing the typical quadrupolar unfolding of two states of oxidation: $\mathrm{FeO}$ and $\mathrm{Fe} 2 \mathrm{O}_{3}$.

ference between $\mathrm{H}_{2} \mathrm{O}+\mathrm{y} \mathrm{H}_{2} \mathrm{O}-$. Octahedral cations are in the range 0.39 to $0.67 \%$. The tetrahedral $\mathrm{Al}$ cation is in the range from $x=1.61$ to 2.28 atoms per formulae unit and with lower octahedral occupancy. It is structurally well balanced but much more variable chemically.

Two triangular diagrams were utilized: (1) $\mathrm{Fe}+\mathrm{Mg}+\mathrm{Mn}$ - $\mathrm{Si}$ - Al and (2) Mg - Fe - Al. Both diagrams show a composition of chamosite that indicates the trend of atoms number per formulae unit functioning in a distinct environment and depositional conditions.

3.2.4 Mössbauer spectroscopy The chamosite spectrum shows the quadrupolar unfolding typical of two states of oxidation: $\mathrm{FeO}$ and $\mathrm{Fe}_{2} \mathrm{O}_{3}$ (Fig. 10).

\section{Discussion}

The chemical and mineralogical characterization of chamosite and berthierine show that both minerals are chemically related but are structurally different. Their close textural relation with magnetite allows a better understanding of its origin and deposition environment. Tables 2 and 3 show the main chemical and structural characteristics of both mineral varieties.

Chamosite is related to the beginning of a hydrothermal phase and occurs mainly in a mineralized breccia type stockwork, in which it fills open spaces and replaces the host rock through fissures. It is associated to magnetite, sulphide, epidote, calcite, quartz, feldspar, clay minerals, and sericite. The chamosite-magnetite textural relationship is characterized by magnetite in veins cutting the host rock replaced by chamosite and epidote, forming a mineralized breccia. This association permits us to demonstrate the epigenetic hydrothermal origin for magnetite, after deposition of chamosite and epidote. After the hydrothermal magnetite deposition, follows the deposition of calcite, quartz, and sulfurs (mainly pyrite and chalcopyrite). These last minerals fills open spaces in magnetite.

Berthierine is the most abundant chlorite, keeps a 5:1 proportion with chamosite, and is related to the final stage of the hydrothermalism of a mineralized stratiform body. Some samples show incipient recrystallization provoked by low-degree metamorphism or by high-grade diagenetic. It is strongly intergrowed into an intergranular shape with botryoidal magnetite of micro- nanometric size, and in colloform belt shapes that fill open spaces into the magnetite-ore. It is related to siderite, calcite, sulfide and organic matter (Fig. 11). Berthierine is a mineral formed by diagenetic processes from chemical precipitates (exhalites) of hydrothernmal origin that were deposited on the marine bottom. The close textural relationship of berthierine with botryoidal magnetite of very fine micrometric size (mean 20 $\mu \mathrm{m})$ and nanometric size (mean $6 \mathrm{~nm}$ ) show a common environment of formation, related to exhalative sedimentary (SEDEX) origin.

Optical properties show clear differences between chamosite and berthierine. Berthierine depict because of its very fine grain size $(<15 \mu \mathrm{m})$ becoming amorphous, and chamosite is distinguished because of its lamellar shape. Berthierine shows more intense colors (dark green and brown) and strong pleochroism. Both minerals coincide in refraction index, ranging from 1.64 to 1.65 , with low birefringence $(<0.008)$ that sometimes is null for berthierine.

The XRD data show: (1) chamosite with $14 \AA$ basal spacing, and (2) berthierine with $7 \AA$ basal spacing. The absence of the $14 \AA$ reflection is decisive in identification of the berthierine (Brindley, 1982).

XRD data of berthierine affected by low-degree metamorphism or high-degree diagenesis (Fig. 3) shows that the $14 \AA$ basal spacing is very weak, thus we suppose that berthierine is at the initial phase of transformation to chamosite. The XRD data and microprobe analyses (EPMA) gave support to the knowledge of structural arrangement types, by mean of calculation of dominant cations (octahedral or tetrahedral) and ions number into the structural formulae. 

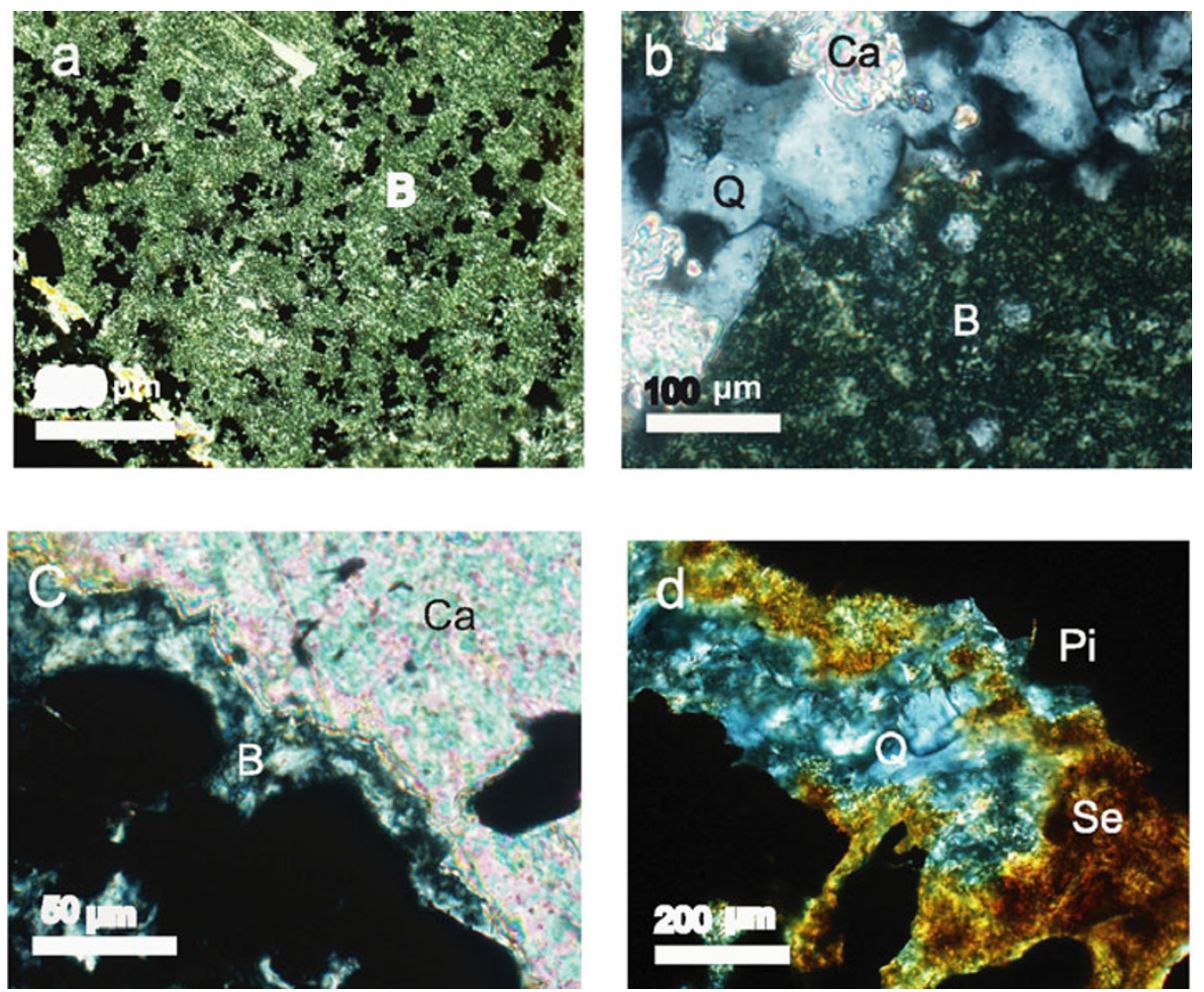

Fig. 11. Microphotographs of berthierine showing mineralogical associations and textural relations. (a) Berthierine (B) in an intergranular matriz with magnetite (black) in micrometric and nanometric scale; (b) Berthierine (B) with quartz veins (Q) and calcite (Ca) filling open spaces in the berthierine and quartz; (c) Colloform band of berthierine filling open spaces between magnetite (black) and calcite (Ca); (d) Pyrite (Pi) surrounded progressively by siderite (Se) and granular quartz (Q).

In base of the structural formulae: $\mathrm{Y}_{6} \mathrm{Z}_{4} \mathrm{O}_{10}(\mathrm{OH})_{8}$, $\left(\mathrm{Y}=\mathrm{Fe}^{2+}, \mathrm{Mg}, \mathrm{Fe}^{3+}, \mathrm{Al} ; \mathrm{Z}=\mathrm{Si}, \mathrm{Al}, \mathrm{Fe}^{+3}\right)$, we calculated the corresponding parameters for the octahedral and tetrahedral components, and the ion number into the structural formulae of the chamosite and berthierine.

The intergranular and colloform banding of berthierine present a $\mathrm{I} b$ polytype structural arrangement with a particular chemical composition, where $\mathrm{R}^{+3}$ radicals substitute $\mathrm{Al}$ and Si forming an orthorhombic (Bailey and Brown, 1962; Brindley, 1951, 1982) or trigonal unit cell (Brindley, 1951, 1982). A Fourier transform image from the HRTEM study shows an hexagonal component [001] [110], supporting the trigonal unit cell. In some areas, the berthierine recrystallizes and the unit cell parameters change from I $b$ to II $b$ polytype, showing a monoclinic unit cell (M). Then the $d=14$ $\AA$ values appear and monoclinic is greater than orthorhombic ( $\mathrm{M} \geq$ Or) (Table 3 ). Diagenetic chlorite are $\mathrm{I} b$ polytype, and during the diagenetic process they change to II $b$ due to recrystallization (Carroll, 1970). The II $b$ polytype is dominant in chamosite with the characteristic monoclinic unit cell in which a major amount of $\mathrm{Al}$ - Si radicals dominate, in the function of the $\mathrm{R}^{+3}=\mathrm{Fe} /(\mathrm{Fe}+\mathrm{Mg}$ ) (Bailey, 1962, 1988) (Fig. 12). Brindley and Youell (1953) demonstrate that both orthorhombic and monoclinic polytypes co-exist in variable proportions.

Chamosite replaced by berthierine in fractures suffers changes in its unit cell predominating Al tetrahedral over $\mathrm{Si}$. We observed that an increase in $\mathrm{Al}^{\mathrm{IV}}$ vs a decrease of ionic radio of $\mathrm{Si}$, together with substitution of octahedral $\mathrm{Fe}$ by $\mathrm{Mg}$, decrease notably the $\mathrm{FeO}$.

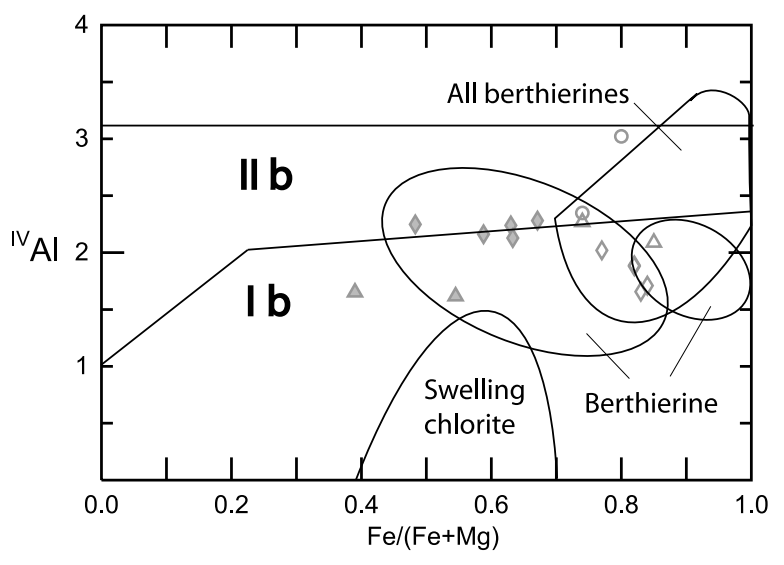

Fig. 12. $\mathrm{Fe} /(\mathrm{Fe}+\mathrm{Mg})$ vs ${ }^{\mathrm{IV}} \mathrm{Al}$ diagram of berthierine and chamosite. Occurrence of intergranular berthierine (open diamonds) and berthierine in colloform banding and open space filling (open triangles), predominate polytype $\mathrm{Ib}$, and $\mathrm{II} b$ for recrystallized berthierine (open circles). Polytype II $b$ dominate in vein of chamosite (solid diamonds), however, in chamosite replaced by berthierine through veins (solid triangles) dominate $\mathrm{Ib}$ polytype.

The octahedral totals are lower than the theoretical (12.0) value for tri-octahedral component of chamosite and berthierine (11.94 ions per unit formulae). The chamosite has a mean value of 12.02 ions per formulae unit. The ion vacant number into the octahedral component ranges from 0.092 to 0.222 for chamosite, and from 0.156 to 0.332 for berthierine. The tetrahedral total for chamosite ranges from 1.165 to $2.281^{\mathrm{IV}} \mathrm{Al}$ ions and from 1.65 to $2.26^{\mathrm{IV}} \mathrm{Al}$ ions 

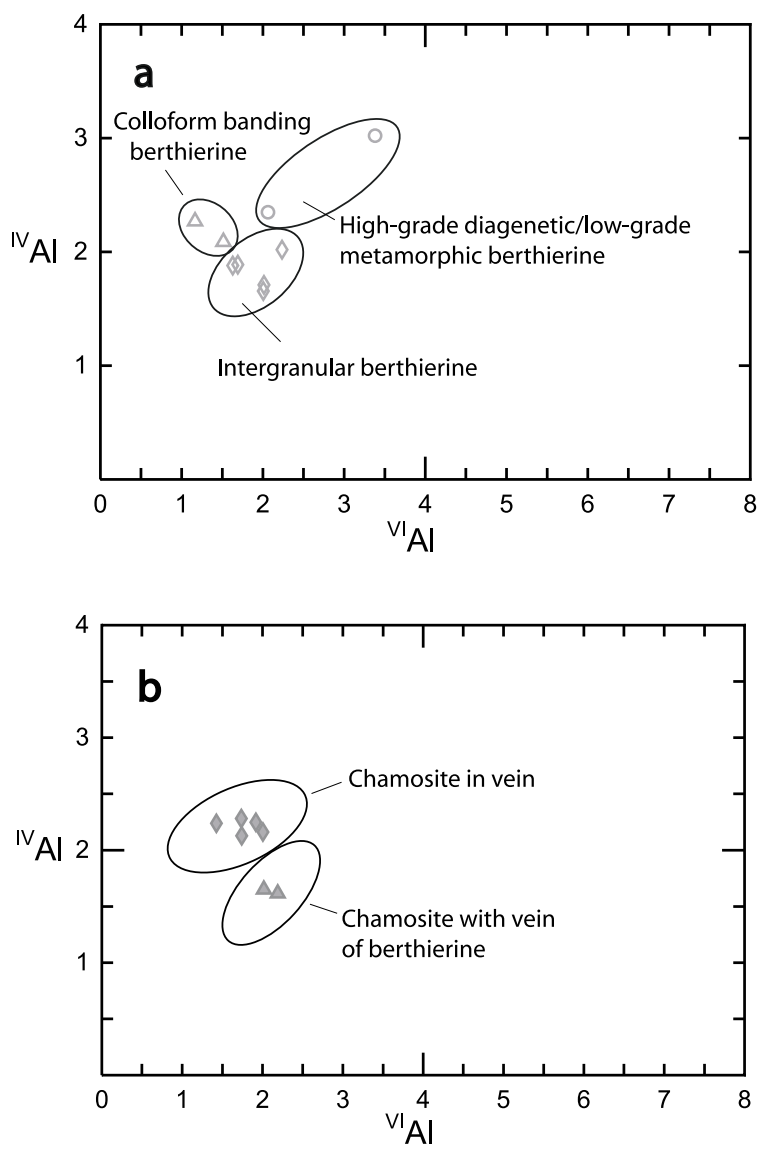

Fig. 13. ${ }^{\mathrm{VI}} \mathrm{AI}$ vs ${ }^{\mathrm{IV}} \mathrm{Al}$ diagrams for berthierine and chamosite in their distinct occurrences.

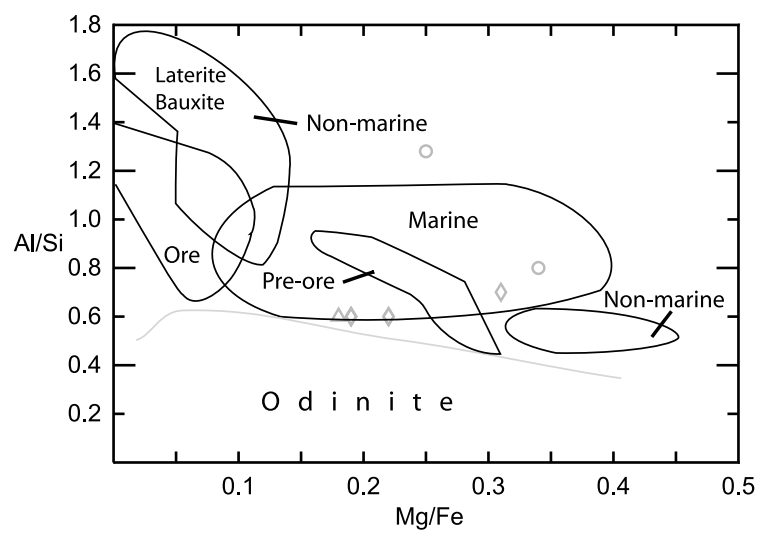

Fig. 14. $\mathrm{Mg} / \mathrm{Fe}$ vs $\mathrm{Al} / \mathrm{Si}$ diagram (Damyanov and Vassileva, 2001). Berthierine data from distinct occurrences (open diamonds, triangles, and circles) suggests a marine origin.

for berthierine per formulae unit. These data show that chamosite has a unit cell more homogeneous and structurally well balanced as opposed to berthierine which has a more unstable unit cell and major number of octahedral vacants.

The relationship between octahedral $\mathrm{Al}\left({ }^{\mathrm{VI}} \mathrm{AI}\right)$ and tetrahedral $\mathrm{Al}\left({ }^{\mathrm{IV}} \mathrm{Al}\right)$ is shown in Fig. 13 for different textural types of chamosite and berthierine. The chamosite that occupy open spaces in the host rocks (veins) contain a major amount of ${ }^{\mathrm{IV}} \mathrm{Al}$ in respect to chamosite associated to colloform berthierine, which depicts the increasing of ${ }^{\mathrm{VI}} \mathrm{AI}$ com-
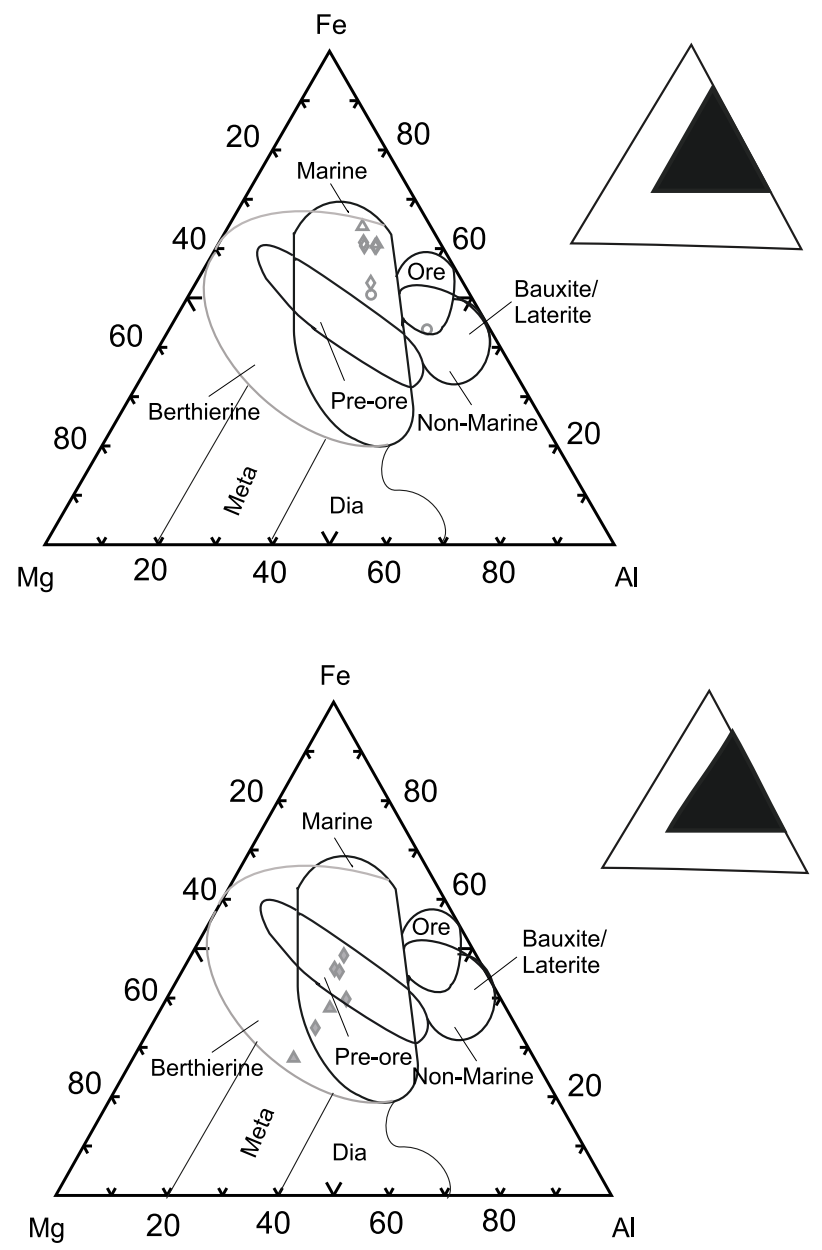

Fig. 15. (a) $\mathrm{Al}$ - Mg - Fe triangle diagram (Velde, 1985; Damyanov and Vassileva, 2001). The berthierine field (open diamonds, open triangles, and open circles) is wider than the proposed by these authors and is in the marine zone. Recrystallized berthierine (open circles) is also in the ore zone. (b) Al - Mg - Fe triangle diagram (Velde, 1985; Damyanov and Vassileva, 2001). The chamosite field (solid diamonds) of vein open space filling and of replacement is in the pre-ore zone. Chamosite associated to berthierine (solid triangles) is out of the pre-ore zone.

ponents possibly due to substitution of Fe ions by $\mathrm{Mg}$. In berthierine, the predominance is of three main textural presentations. In this case, intergranular berthierine contains a minor number of ${ }^{\mathrm{IV}} \mathrm{Al}$ components in respect to berthierine affected by metamorphism or diagenesis in which occur a notable increase of components of ${ }^{\mathrm{IV}} \mathrm{Al}$ with a decrease of $\mathrm{Si}$ and $\mathrm{Fe}$ ions by $\mathrm{Mg}$ substitution.

Figure 14 shows that the marine environment emplacement of the intergranular berthierine (higher content of $\mathrm{Mg} / \mathrm{Fe}$ ) is different to that of metamorphosed berthierine (higher $\mathrm{Al} / \mathrm{Si}$ ). Chemical composition variation of berthierine and chamosite are presented in Figs. 15 and 16. Based in the microprobe analyses (EPMA), we calculated the cationic relationship by formulae unit for the construction of the diagrams $\mathrm{Fe}+\mathrm{Mg}+\mathrm{Mn}-\mathrm{Si}-\mathrm{Al}$ and $\mathrm{Mg}-\mathrm{Fe}-\mathrm{Al}$.

The diagram of Fig. 15 shows the close relationship of berthierine and chamosite with the ore (magnetite) before, during , and after deposition of hydrothermal magnetite. The berthierine samples with a high cation tetrahedral ${ }^{\mathrm{IV}} \mathrm{Al}$ value (recrystallized berthierine) are located in the highdegree diagenetic and low-degree metamorphic zone. 

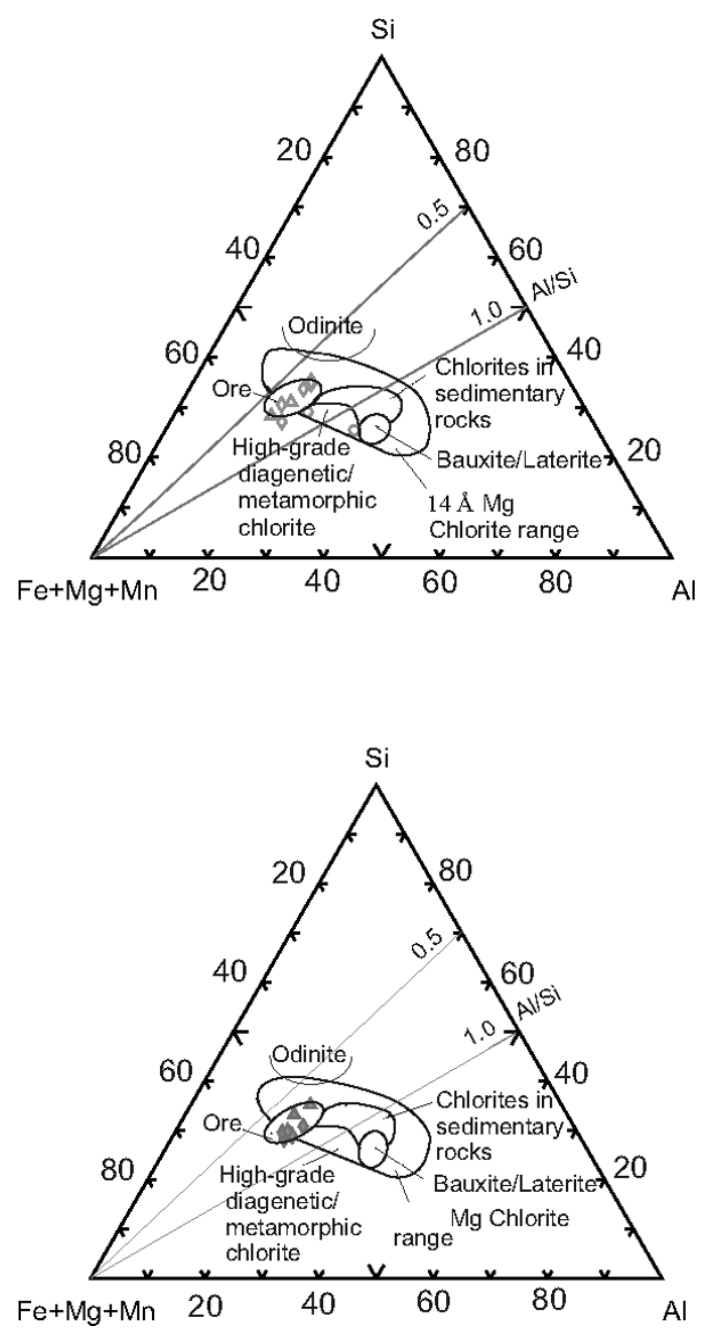

Fig. 16. a) $\mathrm{R}^{2+}-\mathrm{Al}-\mathrm{Si}$ triangle diagram (Velde, 1985; Damyanov and Vassileva, 2001). The berthierine compositions (open diamonds and triangles) are in the ore zone in contrast with the recrystallized berthierine (open circles) that is in the high-grade diagenetic/metamorphic chlorite zone. b) $\mathrm{R}^{2+}-\mathrm{Al}-\mathrm{Si}$ triangle diagram (Velde, 1985; Damyanov and Vassileva, 2001). The chamosite compositions (solid diamonds and triangles) are in the ore zone.

Most of chamosite samples belong to the pre-ore zone in the triangular diagram (Fig. 15), suggesting that they are emplaced at the beginning of the hydrothermal phase, before deposition of magnetite and vein sulphides. Berthierine is in the marine zone, corresponding to a sedimentary exhalative hydrothermal process (SEDEX). Marine chimneys produced the hydrothermal Fe rich brines, in a marine clay floor of relatively shallow depth, provoking the simultaneous precipitation of intergranular berthierine and magnetite. The berthierine with colloform bands was emplaced afterwards.

The sedimentary hydrothermal phase is associated to successive phases of diagenetic precipitation, which occur during and after precipitation of magnetite (Fig. 16). This hydrothermal-diagenetic process supplied the formation of microcrystalline and amorphous berthierine, strongly associated to botryoidal magnetite of micro- and nanometric sizes. Both minerals form the intergranular texture. The botryoidal texture of magnetite in berthierine shows the typ-
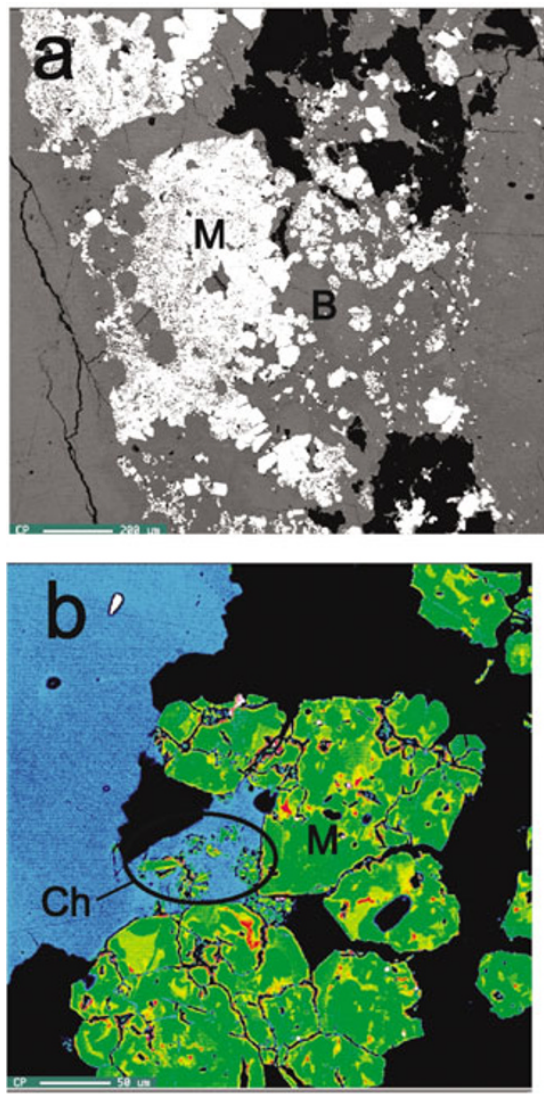

Fig. 17. EPMA images. (a) Berthierine (B) forming an intergranular matrix with magnetite (M), sample M-3. (b) Lamellar chamosite (Ch) replacing the host rock in the mineralized breccia type stockwork (massive magnetite veins $(\mathrm{M})$, sample A-31D.

ical texture of deposition in a sedimentary exhalative environment (Fig. 17). The amorphous phase of berthierine is attributed to an intense ionic change, where Fe replaces $\mathrm{Mg}$ in the dominant octahedral positions of the berthierine formulae unit. The end of the hydrothermal phase is indicated by the presence of berthierine filling open spaces and forming colloform bands contiguous to magnetite grains.

Berthierine is also associated to siderite and organic matter. Precipitation of siderite occur when there is a low concentration of iron sulfur (pyrite), high accumulation of carbonates and $\mathrm{Fe}$, high $\mathrm{Fe}^{2+} / \mathrm{Ca}$ radio, low $\mathrm{Eh}$ and $\mathrm{pH}$ close to 7 .

The emplacement of berthierine-magnetite exhalative hydrothermal took place after chamosite deposition and it is related to the more important stratiform structure into the Peña Colorada deposit.

McDowell and Elders (1980) use authigenic phyllosilicates in sedimentary deposits to determine the thermal gradient, considering the microprobe chlorite analyses. They found that low total octahedral $(-11.0$ corresponds to temperature of $150^{\circ} \mathrm{C}$ ) relates to relatively shallow depth and closed unit cell (with a theoretical value of 12) at a temperature of $360^{\circ} \mathrm{C}$.

Chamosite has a low total octahedric mean $=12.02$ per formulae unit. Therefore, correspond to a crystallization temperature close to $360^{\circ} \mathrm{C}$. Berthierine has total octahedric mean $=11.94$ corresponding to a crystallization temperature 
close to $150^{\circ} \mathrm{C}$.

Two main genetic episodes occur during the berthierine and chamosite formation in the Peña Colorada Mine: (1) The berthierine of hydrothermal origin precipitates by diagenetic processes at the sea bottom; (2) The chamosite of hydrothermal origin was emplaced in open spaces into the host rock (there is replacement evidence, Fig. 16 and 17).

A high concentration of $\mathrm{Al}$ has been observed in recent geothermal areas associated to marine basins, which suggests the importance of the Al phyllosilicates, particularly berthierine of SEDEX deposits (Damyanov and Vassileva, 2001). This relationship allows the use of berthierine and chamosite as geologic environment indicators.

\section{Conclusions}

By virtue of its composition, texture, and mineralogical associations of chamosite and berthierine, two mineralization stages and environment of deposition, closely related to the main magnetite ore are recognized: (1) Chamosite epigenetic hydrothermal; and (2) Berthierine hydrothermal sedimentary exhalative (SEDEX).

The first hydrothermal process in the Peña Colorada deposit took place at the end of the Cretaceous epoch, and is characterized by chamosite replacing the host rock (feldspar hornfels) through fractures and filling open spaces in the same host rock. This host rock produced a mineralized breccia type stockwork, with massive magnetite veins cutting the host rock in several directions. Chamosite is associated to magnetite, sericite, clay minerals, quartz, epidote and sulfides.

The berthierine precipitation during and after magnetite deposition indicate the end of the hydrothermal phase, possibly at the beginning of Tertiary. Berthierine was formed by hydrothermal and diagenetic processes in a marine sedimentary exhalative environment (SEDEX). This environment was favorable for the very fine grain (microcrystalline to amorphous) berthierine deposition. Berthierine occurs mainly in two textural shapes: (1) intergranular; and (2) filling open spaces in the host rock forming colloform bands. Berthierine is associated to siderite, organic matter, botryoidal magnetite, and magnetite nanoparticles. The SEDEX body is related to the most important stratiform structure located in the Peña Colorada iron-ore deposit.

The micro-and nanoparticles of magnetite are homogeneously distributed in the amorphous area of the berthierine. They are associated with sedimentary exhalative origin.

Acknowledgments. We thank to the Consorcio Minero Benito Juárez, Peña Colorada for supplying the mine products. We also appreciate the kind help of Ernesto Aguilera Torres (Laboratorio Experimental México de la CFM), Margarita Reyes and Carlos Linares (Laboratorio de Petrología del Instituto de Geofísica, UNAM) and Luis Rendón (Laboratorio Central de Microscopía del Instituto de Física). Finally, we thank the financial support of DGAPA-UNAM research Project IN-108605.

\section{References}

Bailey, S. W., X-Ray diffraction identification of the polytypes of mica, serpentine and chlorite, Clays and Clay Minerals, 36(3), 193-213, 1988. Bailey, S. W., Structures and composition of other trioctahedral 1:1 phyllosilicates, Hydrous Phyllosilicates (exclusive of micas), Reviews in mineralogy, 19, 179-181, 1991.

Bailey, S. W. and B. E. Brown, Chorite polytypism: I. Regular and semirandom one-layer structures, Americal Mineral., 47, 819-850, 1962.

Bhattacharyya, D. P., Origin of berthierine in ironstones, Clays and Clay Minerals, 31(3), 173-182, 1983.

Brindley, G. W., Chemical compositions of berthierine-a review, Clays and clay Minerals, 30(2), 151-155, 1982.

Brindley, G. W., The crystal structures of some chamosite minerals, Mineral. Mag., 29, 502-525, 1951.

Brindley, G. W., Kaolin, serpentine, and Kindred minerals, in The X-ray Identification and Crystal Structures of Clay Minerals, edited by G. Brown, Mineralogical Society London, pp. 51-131, 1961.

Brindley, G. W. and R. F. Youell, Ferrous chamosite and ferric chamosite, Mineralog. Mag., 30, 220, 57-70, 1953.

Carroll, D., Clay Minerals: A Guide to their X-ray Identification, The Geological Society of America, Special Paper, 126, 1970.

Curtis, C. D. and D. A. Spears, The formation of sedimentary Iron Minerals, Econ. Geol., 67, 257-270, 1968.

Damyanov, Z. and M. Vassileva, Authigenic phyllosilicates in the middle Triassic Kremikovtsi sedimentary exhalative siderite iron formation, Western Balkan, Bulgaria, Clays and Clay Minerals, 49, 6, 559-585, 2001

Deer, W. A., R. A. Howie, and J. Zussman, Rock-Forming Minerals. Vol. 5 Non-Silicates, John Wiley and Sons Inc., pp. 62-124, 1993.

Del Mar Abad-Ortega, M. and F. Nieto, Extension and closure of the compositional gap between $\mathrm{Mn}$ and $\mathrm{Mg}$ rich chorites toward $\mathrm{Fe}$-rich compositions, European J. Mineral., 7(2), 363-367, 1995.

Hayes, J. B., Polytypism of chorite in sedimentary rocks, Clays and Clay Minerals, 18, 285-306, 1970.

Heinrich, E. W., Microscopic Identification of Minerals, McGraw-Hill Book Company, 1965

Hirt, A. M. and A. U. Gehring, Thermal alteration of the magnetic mineralogy in ferruginous rocks, J. Geophys. Res., 96(B6), 9947-9953, 1991.

Iijima, A. and R. Matsumoto, Berthierine and chamosite in coal measures of Japan, Clay and clay Minerals, 30(4), 264-274, 1982.

Kimberley, M., Exhalative origins of iron formations, Ore Geol. Rev., 5, 13145, 1989.

McDowell, S. D. and W. A. Elders, Authigenic layer silicate minerals in borehole Elmore I, Salton Sea geothermal field, California, USA, Contrib. Mineral. Petrol., 74, 293-310, 1980.

Pirajno, F., Hydrothermal mineral deposits, in Principles and Fundamental Concepts for the Exploration Geologist, SpringerVerlag Berlin Heidelberg, 1992.

Retallack, G., Reappraisal of a 2200 Ma-old paleosol near Waterval Onder, South Africa, Precambrian Res., 32(2-3), 195-232, 1986.

Slack, J. F., J. Wel-The, D. R. Peacor, and P. M. Okita, Hydrothermal and metamorphic berthierine from the Kidd Creek volcanogenic massive sulfide deposit, Timmins, Ontario, Can. Mineralogist, 30, 1127-1142, 1992

Toth, T. A. and S. J. Fritz, An Fe-berthierine from a Cretaceous laterite: Part I. Charaterization, Clays and Clay Minerals, 45(4), 564-579, 1997.

Velde, B., Clay minerals: A physicochemical explanation of their occurrence, Developments in Sedimentology 40, Elsevier, Amsterdam, 1985.

White, S. H., J. M. Huggett, and H. F. Shaw, Electron-optical studies of phyllosilicate intergrowths in sedimentary and metamorphic rocks, Mineral. Magazine, 49, 413-423, 1985.

Wiewiora, A., A. Wilamowski, L. Bozena, M. Kuzniarski, and D. Grabska, Chamosite from oolitic ironstones: The necessity of a combined XRDEDX approach, Can. Mineralogist, 36, 1547-1557, 1998.

Wybrecht, E, J. Duplay, A. Piqué, and F. Weber, Mineralogical and chemical evolution of whit micas and chlorites, from diagenesis to low-grade metamorphism; data from various size fractions of greywackes (Middle Cambrian, Morocco), Mineral. Magazine, 49, 401-411, 1985.

$\mathrm{Xu}, \mathrm{H}$. and D. R. Veblen, Interstratification and other reaction microstructures in the chlorite-berthierine series, Contrib. Mineral Petrol., 124, 291-301, 1996

Yoshida, K., Formation of plications in the Miocene bivalve Mytilus (Plicatomytilus) ksakurai as a consequence of architectural constraint, $\mathrm{Pa}$ leontol. Res., 2(4), 224-238, 1998.

M. L. Rivas-Sanchez, L. M. Alva-Valdivia (e-mail: lalva@geofisica. unam.mx), J. Arenas-Alatorre, J. Urrutia-Fucugauchi, M. Ruiz-Sandoval, and M. A. Ramos-Molina 